\title{
TRES DÉCADAS DE EVOLUCIÓN CONSTITUCIONAL EN PORTUGAL (1976-2006)
}

\author{
POR \\ ANDONI PÉREZ AYALA \\ Profesor Titular de Derecho Constitucional Comparado \\ Universidad del País Vasco
}

\section{LA SINGULARIDAD CONSTITUCIONAL PORTUGUESA}

La evolución constitucional portuguesa durante las tres últimas décadas presenta rasgos acusadamente distintivos en relación con la que han seguido otros países de su entorno en el mismo periodo temporal. Esta marcada diferenciación de la evolución constitucional de la República portuguesa sólo puede ser comprendida adecuadamente si partimos del hecho de su singularidad constitucional originaria, plasmada en términos jurídico-políticos en el texto aprobado por el constituyente de $1976^{1}$. No se trata sólo de un texto constitucional que presenta características propias y diferenciadas (todos los textos constitucionales tienen, en mayor o menor medida, características distintivas propias), sino que la obra del constituyente portugués surgido de la revolución de los claveles introduce una serie de elementos acusadamente dispares o, incluso, abiertamente contradictorios en algunos casos, con los del modelo constitucional común a los países de nuestro entorno.

1 Sobre la versión originaria de la Constitución portuguesa, vid. J. MIRANDA: Formaçao, Estrutura, Principios fundamentais, Livraría Petrony, Lisboa, 1978. Así mismo, J. J. Gomes Canotilho y Vital Moreira: Constituçao da Republica Portuguesa Anotada, Coimbra, 1978. 
Singularidad constitucional que llama la atención desde el primer momento, tanto desde el punto de vista formal como por lo que se refiere a su contenido material. En relación con el primero, cabe reseñar la desmedida extensión del texto constitucional (312 disposiciones constitucionales; algunas de ellas, además, inusualmente largas), la forma excesivamente detallista y pormenorizada de regular algunas materias o la propia estructura del texto constitucional y la ordenación de las materias que trata. En lo que concierne a su contenido material, hay que mencionar la regulación de materias que no son objeto de tratamiento constitucional en otros textos, o no de forma tan directa y extensa (así, por ej., la reforma agraria, los sectores productivos, la planificación económica, y todo lo relacionado con la organización económica, en general); a lo que, en el plano institucional habría que añadir la constitucionalización expresa de instancias con difícil encaje en nuestro modelo constitucional, tales como el Movimiento de las Fuerzas Armadas o el Consejo de la Revolución. Todo ello configura el punto de partida del que necesariamente hemos de arrancar para poder comprender adecuadamente la evolución constitucional portuguesa durante las tres últimas décadas.

1. La causa inmediata de la llamativa singularidad constitucional portuguesa se halla en la excepcional coyuntura político-militar de la revolución de los claveles, que al tiempo que ponía fin al régimen dictatorial existente abría el camino a un proceso constituyente que culminará, dos años después, con la aprobación del texto constitucional de 1976. Sorprendentemente, y al contrario de lo que suele ocurrir cuando el Ejército irrumpe en la escena política, en Portugal es precisamente la intervención de las Fuerzas Armadas la que hace posible la instauración de la democracia constitucional. Para ser más precisos, de un sector de las FF.AA. aglutinado en torno al Movimiento de las Fuerzas Armadas (MFA), impregnado de un fuerte radicalismo socializante, que va a ejercer una influencia determinante en el desarrollo del proceso constituyente $^{2}$ y cuyas peculiares posiciones, como tendremos ocasión de comprobar a continuación, tendrán un importante reflejo en el texto constitucional originario de 1976.

2 La literatura sobre el papel de los militares portugueses en la instauración del nuevo régimen constitucional es muy amplia, no sólo en Portugal sino también en otros países. Vid. al respecto, entre otras, la obra colectiva O Movimento dos Capitanes e o 25 Abril, Lisboa, 1974. Así mismo, HARDY: "Portugal. Anatomie du nouveau pouvoir militaire", Les Temps Modernes, 1974, pp. 350 y ss.; N. BouRDILLAT: "Portugal. Le MFA et l'institution militaire dans la revolution des oeillets", en la obra colectiva (A. ROUQUIE, comp.) La politique de Mars. Les processus politiques dans les partis militaires contemporaines, Ed. La Sycomore, Paris, 1981. 
Es precisamente en esta huella que deja impresa el MFA en el constituyente de 1975-76 donde radica el factor determinante de la singularidad constitucional portuguesa, que tendrá su plasmación jurídico-política en el texto originario de 1976. Lo primero que salta a la vista en él es el tratamiento radicalmente distinto que, en relación con otros textos constitucionales de la misma área geográfica y política, tienen las distintas materias; desde los principios fundamentales (disposiciones preliminares) hasta la peculiar organización institucional, con la incorporación de órganos inéditos en nuestro modelo constitucional; o, así mismo, en materia de derechos y libertades; o, de forma muy especial, en todo lo concerniente a la organización económica, donde la disparidad es mayor; o, finalmente, en la forma como se contempla la propia revisión constitucional, lo que condiciona la forma como han venido realizándose éstas.

Esta acusada disparidad del texto constitucional portugués originario en relación con el modelo constitucional vigente en los países de nuestro entorno hizo que, desde el primer momento, empezara a plantearse la conveniencia de una amplia revisión de la obra del constituyente de 1976. Iniciada ésta tras la conclusión de la I legislatura (197680), el legislador constitucional portugués ha venido desarrollando desde entonces hasta la actualidad una intensa actividad, plasmada en siete revisiones ${ }^{3}$ (algunas de ellas extraordinariamente amplias y profundas, como tendremos ocasión de comprobar) que, conjuntamente, nos proporcionan el material que mejor puede ilustrar la compleja evolución constitucional seguida por la República portuguesa durante estas tres últimas décadas.

2. Junto a la excepcionalidad de la coyuntura político-militar constituyente, causa inmediata de la singularidad constitucional portuguesa, es preciso reseñar también la particular trayectoria histórica seguida por el constitucionalismo portugués hasta 1976. En este sentido, es obligado constatar la ausencia de precedentes históricos que pudieran servir como marco de referencia al constituyente portugués tras la caída de la dictadura en 1974. Obviamente, no podía servir como referencia la "Constitución» salazarista de $1933^{4}$, que tan sólo había servido

3 En 1982, 1989, 1992, 1997, 2001, 2004 y 2005, que examinaremos a lo largo de este trabajo. Un breve comentario sobre cada una de estas revisiones puede verse en F. PAULO GonçALVES: "Las revisiones de la Constitución de 1976", en AA.VV. (J. TAJADURA, coord): La Constitución portuguesa de 1976, Centro de Estudios Políticos y Constiucionales (CEPC), Madrid, 2006, pp. 291 y ss.

${ }_{4}$ Tiene especial interés, dada la personalidad de su autor (último Jefe de gobierno del régimen salazarista) la obra de M. CAETANo: Manual de Ciencia Política e Direito Constitucional, Vol II, Lisboa, 1972. 
para proporcionar cobertura al prolongado régimen dictatorial de $\mathrm{O}$. Salazar, al que precisamente la revolución de los claveles acababa de poner fin. Hay que anotar, sin embargo, que se trata del único caso de régimen dictatorial que pretende mantener una apariencia constitucional, lo que no deja de ser otra curiosa peculiaridad "constitucional» que carece de correspondencia en regímenes de similares características.

Tampoco las experiencias constitucionales previas al largo periodo dictatorial podían proporcionar referencias válidas al constituyente de 1976. La Constitución republicana de 1911, además de su lejanía en el tiempo, no sólo se reveló incapaz para proporcionar un marco estable al desarrollo de la vida política portuguesa sino que fue el escenario de uno de sus periodos más agitados y convulsos (1911-1926), abocando finalmente al régimen dictatorial instaurado a partir de 1926. Más lejana aun en el tiempo, y sobre todo políticamente, resultaba la experiencia, muy discutiblemente constitucional, de la Monarquía a lo largo del siglo XIX. Baste reseñar que el texto que estuvo formalmente vigente hasta 1910 fue la Carta constitucional de 1826, que a pesar de las sucesivas Actas adicionales añadidas dudosamente puede ser considerado como un texto capaz de fundamentar un régimen constitucional digno de tal nombre 5 .

No es de extrañar que ante la ausencia de referencias constitucionales históricas válidas, el constituyente de 1976 se viese obligado a adoptar posiciones que podrían ser caracterizadas como de adanismo constitucional; al menos, en relación con los propios antecedentes históricos o, para ser más precisos, con la ausencia de experiencias históricas que pudiesen proporcionar referencias válidas. O también, como suele ser frecuente cuando se trata de instaurar un nuevo régimen constitucional, buscar las referencias que no es posible hallar en la propia experiencia histórica en la experiencia constitucional comparada; como, efectivamente, así ocurrió en el caso del constituyente portugués surgido de la revolución de los claveles.

3. Las tendencias constitucionales que prevalecen en Europa a mediados de la década de los setenta, periodo en el que se desarrolla el proceso que culminará con la adopción del peculiar modelo constitucional portugués, van a ejercer un influjo determinante en el constitu-

5 Sobre la evolución histórica del constitucionalismo portugués, vid. J. MIRANDA: As Constituiçoes portuguesas. De 1822 ao Texto Actual da Constituçao, Livraría Petrony, Lisboa, 2004. Una breve síntesis, del mismo autor, puede verse en "La Constitución de 1976 en el ámbito del constitucionalismo portugués", Revista de Estudios Políticos, n. ${ }^{\text {os }}$ 60-61, 1988 (monográfico sobre el sistema político y constitucional portugués). 
yente de 1976. En primer lugar, y por lo que se refiere a Europa occidental, es la época de mayor auge de las posiciones vinculadas al Estado y al constitucionalismo sociales. Aunque estas posiciones empezarán a perder terreno precisamente a partir de este momento, cediendo ante el empuje neoliberal a partir de la segunda mitad de la década de los setenta, en el periodo en el que se acomete la tarea de construir el nuevo orden constitucional para Portugal (1974-76), el modelo de referencia dominante en todos los países de Europa occidental no es otro que el del constitucionalismo del Estado social, que en ese momento tiene aceptación generalizada.

Por otra parte, el modelo constitucional de inspiración marxista propio de las democracias populares de los entonces denominados Países del Este ejerció también una influencia nada desdeñable sobre el constituyente portugués de $1976^{6}$. Si bien se trata de un modelo constitucional que en la actualidad ha desaparecido, no puede olvidarse que en el momento en que se desarrolla el proceso constituyente en Portugal era un modelo de referencia vigente. En particular, la influencia sobre el constituyente portugués es fácilmente detectable, de forma especial, en el tratamiento de aspectos relacionados con materias económicas y sociales (como se examinará más ampliamente en su momento). Ello contribuye a acentuar la singularidad del modelo constitucional portugués en relación con el modelo constitucional existente en los países de su entorno.

Hay que reseñar, por último, el influjo que ejercieron asimismo sobre el constituyente portugués las corrientes de signo anticolonial ${ }^{7}$, también en auge a mediados de la década de los setenta. Si bien Portugal no era un país colonizado - por el contrario, era un país colonizador- no hay que olvidar que es precisamente el conflicto colonial el factor detonante que da lugar a la intervención de las FF.AA. En este marco, el sector más activo de éstas, aglutinado en torno al Movimiento de las Fuerzas Armadas (MFA), va a experimentar un proceso de radicalización anticolonialista, precisamente coincidiendo con el desarrollo del proceso constituyente, que acabará teniendo un importante reflejo en el texto constitucional de 1976; en particular, en algunos enunciados de los principios fundamentales o en algunas instancias institucionales, tales como el MFA o el Consejo de la Revolución ${ }^{8}$.

6 Sobre este modelo constitucional, vid. T. DraganU: Structures et institutions constitutionnelles des pays socialistes européens, Ed. Economica, Paris, 1981.

7 Vid. P. LUCAS VERDU: "Dimensión axiológica de la Constitución portuguesa», en AA.VV. (J. Miranda, org.): Perspectivas Constitucionais. Nos 20 anos da Constituiçao de 1976, Coimbra Edit., 1996, p. 96.

8 Vid. G. DE VergottinI: Diritto Costituzionale Comparato, II, CEDAM, Padova, 2004 , pp. 299 y ss. 


\section{LA VERSION ORIGINARIA (1976) DE LA CONSTITUCION PORTUGUESA}

El texto aprobado por la asamblea constituyente portuguesa en Abril de 1976 es un producto de la concurrencia de los factores reseñados en los párrafos precedentes: excepcionalidad de la coyuntura político-militar de la revolución de los claveles y protagonismo del MFA en el proceso constituyente; particularidad de la trayectoria histórica portuguesa y ausencia de referentes constitucionales en ella que pudieran servir para diseñar el nuevo marco constitucional de 1976; e influjo, además del constitucionalismo social europeo de la época, del constitucionalismo de las democracias populares de los países del Este y también, en alguna forma, del constitucionalismo de la descolonización. Todo ello da lugar a un texto constitucional con características acusadamente singulares, inédito en muchos aspectos, que tiene difícil correspondencia en el constitucionalismo comparado europeo de la épo$\mathrm{ca}^{9}$. Y es precisamente esta singularidad constitucional originaria lo que constituye, como ya se ha señalado, el punto de partida obligado para poder comprender adecuadamente la evolución constitucional portuguesa en las tres últimas décadas.

Además de la inusitada extensión del texto constitucional ${ }^{10}$, Ilama la atención los términos en que está redactado éste, sobre todo en su versión originaria de 1976. En este sentido, resulta muy llamativa la forma de explicitar las convicciones ideológicas que animan al constituyente portugués de la revolución de los claveles. Conviene puntualizar, a este respecto, que si bien en todas las Constituciones subyacen unos presupuestos ideológicos, el rasgo distintivo en el caso portugués es la peculiar forma de explicitarlos. No suelen ser nada comunes en los textos constitucionales expresiones como las que aluden a "la transformación en una sociedad sin clases», a "la transición al socialismo», a "la abolición de la explotación y la opresión del hombre por el hombre» o al "proceso revolucionario", todas ellas incluidas de forma expresa"

9 Un amplio estudio sobre el modelo constitucional originario portugués puede verse en G. DE VeRgottinI: Le origini della Seconda Repubblica Portoghese, Giuffrè Ed., Milano, 1977.

10 Se trata del texto constitucional más extenso, con diferencia, de todos los europeos, sólo equiparable con el de la Constitución yugoslava de 1974, hace tiempo desaparecida. Una recopilación, en lengua castellana, de todos los textos constitucionales europeos de la época puede verse en M. DARANAS: Las Constituciones Europeas, Vol I y II, Editora Nacional, Madrid, 1979.

11 En palabras expresivas de J. J. Gomes CANOTILHO, se trata de la peculiar metanarrativa constitucional portuguesa, Direito Constitucional e Teoria da Constituiçao, Almedina, Coimbra, 2003, p. 208. 
entre los principios fundamentales del orden constitucional republicano.

Otro de los rasgos distintivos del texto constitucional originario de 1976 es la amplia regulación que se hace en él de materias que no suelen ser objeto de tratamiento en otras Constituciones; en particular, en el terreno económico y social. Así, por ejemplo, se dedican sendos Títulos específicos a "las estructuras de la propiedad de los medios de producción» o a "los circuitos comerciales" (Títulos II y VI de la Segunda Parte, sobre la Organización económica), además de los que, con carácter acusadamente programático, se destinan, en el mismo pasaje constitucional, a la planificación económica o a la reforma agraria (Tits. III y IV), lo que no suele ser nada usual en los textos de nuestro modelo constitucional ${ }^{12}$. Así mismo, llama la atención la regulación inusualmente extensa de "los poderes locales", a los que se dedican nada menos que treinta disposiciones constitucionales (arts. 237-266, Tit. VIII de la Tercera Parte); o la dedicatoria de un Título específico a la FF.AA. (Tit. $X$ de la Tercera Parte). Se trata de una serie de elementos que integran el peculiar modelo constitucional originario portugués (1976) pero que carecen de correspondencia en la experiencia constitucional comparada de los países de nuestro entorno.

1. Ya desde el Preámbulo se ponen de manifiesto algunos rasgos distintivos que singularizan la Constitución portuguesa en relación con otros textos constitucionales de su entorno ${ }^{13}$. Así, la invocación de "la Revolución" como el hecho fundante y origen del nuevo régimen constitucional: "La Revolución ha devuelto a los portugueses los derechos y libertades fundamentales..." (par. $3 .^{\circ}$ del Preámbulo). Esta legitimidad revolucionaria de origen hay que combinarla con la legitimidad democrática, a la que inmediatamente a continuación hace referencia expresa el mismo párrafo preambular: "En ejercicio de estos derechos y libertades los legítimos representantes del pueblo se han reunido para elaborar la Constitución...".

La singularidad resultante de la combinación de la legitimidad revolucionaria y la democrática en el origen fundacional del nuevo régi-

12 Sobre la peculiaridad de la Constitución económica portuguesa en su versión originaria, vid. mi trabajo sobre "La revisión de la Constitución económica: del radicalismo socializante a la integración económica en la UE», en AA.VV.: La Constitución portuguesa de 1976, op. cit., Madrid, 2006, pp. 93 y ss.

13 Sobre el Preámbulo de la Constitución portuguesa, vid. J.J. Gomes CANOTILHO: "Preámbulo de la Constitución de Portugal de 1976», en AA.VV. (A. TORRES DEL MORAL y J. TAJAdurA, dirs.): Los Preámbulos constitucionales en Iberoamérica, C.E.P.C., Madrid, 2001, pp. 369 y ss. 
men constitucional portugués (lo que no es posible hallar en otros coetáneos), se acrecienta al fijar los grandes objetivos que el propio texto preambular determina: además de los de carácter general, tales como la defensa de la independencia nacional, de los derechos fundamentales de los ciudadanos, de los principios básicos de la democracia y del Estado de derecho, la Asamblea constituyente proclama expresamente la decisión de "abrir la senda hacia la sociedad socialista", formulación que resulta insólita como objetivo constitucional (en nuestro modelo constitucional); y que sólo se explica, como muchas otras del mismo signo, en el marco de la excepcional coyuntura político-militar que siguió a la revolución de los claveles, durante el periodo constituyente.

Hay que puntualizar que, a diferencia de las alusiones al socialismo en el articulado de la Constitución, que serán eliminadas en el curso de las sucesivas revisiones constitucionales posteriores, ésta, ubicada en el Preámbulo, se mantiene en los mismos términos en que fue redactada por el constituyente de 1976. Hasta ahora, se ha querido preservar íntegro el Preámbulo (a diferencia de lo que ha ocurrido con el resto de la Constitución) como homenaje al constituyente y como recuerdo inalterable del origen del actual régimen constitucional ${ }^{14}$. En cualquier caso, tanto la proclamación de la legitimidad democrático-revolucionaria como del objetivo socialista no dejan de ser elementos que contribuyen a la singularización del modelo constitucional portugués.

2. En las disposiciones preliminares, dedicadas a establecer los Principios fundamentales (arts. 1-11) del nuevo orden constitucional de la República portuguesa, llama la atención la presencia de una serie de elementos, sin correspondencia en el constitucionalismo europeo-occidental, que resultan ciertamente sorprendentes tanto por su contenido como por los términos en que están formulados. Así, se fijan como objetivos globales de la República «...empeñada en la transformación de una sociedad sin clases" (art. 1) "... asegurar la transición hacia el socialismo mediante la creación de condiciones para el ejercicio democrático del poder por la clases trabajadoras" (art. 2) ${ }^{15}$; en esta misma

14 Los sucesivos legisladores constitucionales han optado por mantener intacto lo que, en palabras expresivas de J. J. CANOtILHo y VITAL MOREIRA (Constituiçao da República Portuguesa Anotada, Coimbra Ed., 1984, p. 44), constituye el "certificado de origen" del actual régimen constitucional portugués.

15 Para un comentario más amplio sobre estas dos disposiciones constitucionales iniciales en su versión originaria, vid. J. MIRANDA: "O art. $1 .{ }^{\circ}$ e art. $2 .^{\circ}$ da Constituçao", en AA.VV.: Estudos sobre a Constituiçao, Livraría Petrony, Lisboa, 1978, pp. 9 y ss. 
orientación, al fijar las misiones fundamentales del Estado, se le atribuye expresamente la de "socializar los medios de producción y la riqueza" (art. 9.c).

En el plano de las relaciones internacionales, además de la alusión a los principios generales de igualdad entre los Estados, solución pacífica de los conflictos internacionales, no injerencia en asuntos internos y cooperación entre los pueblos, admitidos todos ellos comúnmente en la comunidad internacional, se constitucionaliza explícitamente el derecho de los pueblos a la autodeterminación, y a "la insurrección contra todas las formas de opresión, especialmente contra el colonialismo y el imperialismo", que son objeto de un pronunciamiento constitucional expreso en pro de su abolición; así como en favor del «desarme general, simultáneo y controlado y la disolución de los bloques políticomilitares" (art.7.2), pronunciamiento este último que tiene especial significación en un momento (mediados de la década de los setenta) en que la dinámica de bloques era la que condicionaba todas las relaciones internacionales, perteneciendo Portugal a uno de ellos como miembro fundador ${ }^{16}$.

Encuadrado también entre las disposiciones preliminares relativas a los Principios fundamentales, hallamos un insólito precepto dedicado a constitucionalizar el proceso revolucionario (art. 10) ${ }^{17}$, cuyo desarrollo, se precisa, «impone en el plano económico la apropiación colectiva de los principales medios de producción" mediante "la alianza entre el Movimiento de la Fuerzas Armadas y los partidos y organizaciones democráticos». Particular atención merece la constitucionalización, dentro de las disposiciones preliminares relativas a los Principios fundamentales, del Movimiento de las Fuerzas Armadas (MFA), "en su calidad de garante de las conquistas democráticas y del proceso revolucionario", previendo expresamente, además, su participación, "en alianza con el pueblo, en el ejercicio de la soberanía, según los términos de la Constitución» (art. 3.2).

16 Portugal es uno de los países que suscriben, en 1949, el Tratado de Washington, del que surge la OTAN, sin duda el bloque militar más importante en la actualidad, en cuya estructura militar está integrado Portugal desde el primer momento.

17 La revolución y el proceso revolucionario no sólo eran un elemento importante en el discurso de las fuerzas políticas en el periodo constituyente sino que también era un tema que atraía la atención de juristas y constitucionalistas. Vid. en este sentido, J. Miranda: "A Revoluçao de 25 de Abril e a Constituiçao", Boletim do Ministério da Justiça (BMJ), Enero 1975, pp. 5 y ss. Así mismo, M. DE LUCENA: O Estado da RevoIuçao. A Constituiçao de 1976, Lisboa, 1978. M. G. TELES: "O problema da continuidade da orden Jurídica e a Revoluçao portuguesa", $B M J$, n. ${ }^{\text {os }} 345,1985$, pp. 25 y ss. 
Como puede observarse, se trata de formulaciones que presentan diferencias notables con las que suelen ser propias del modelo constitucional que rige en nuestro ámbito geográfico y político. Si bien todas ellas fueron eliminadas en las sucesivas revisiones constitucionales que tuvieron lugar posteriormente, su referencia es obligada para poder comprender adecuadamente la evolución constitucional portuguesa durante las tres últimas décadas. Aunque a lo largo de este trabajo nos ocuparemos con mayor detenimiento de ello, hay que avanzar que este pasaje constitucional (juntamente con el relativo a la Constitución económica y a algunos aspectos de la organización institucional) es el que ha experimentado modificaciones de mayor entidad.

3. De las cuatro partes en que se divide el extenso texto constitucional portugués (312 arts. $)^{18}$, la primera de ellas se dedica a regular, de forma especialmente amplia, los derechos y deberes fundamentales. Llama la atención, antes de nada, la inusual extensión que tiene esta regulación (arts. 12-79), lo que permite un tratamiento muy pormenorizado de la materia. Subdividido en tres Títulos, el primero de ellos se dedica a establecer los principios generales del régimen de derechos y libertades, enumerando a continuación, en dos bloques diferenciados, los derechos y libertades civiles y políticos (Tit. II, arts. 25-49) y los derechos económicos, sociales y culturales (Tit. III, arts. 50-79). Tanto por su extensión como por su estructura y contenido, esta regulación presenta rasgos distintivos propios en relación con la que se hace de esta misma materia en otros textos constitucionales ${ }^{19}$.

Es de reseñar la agrupación en dos bloques diferenciados del largo listado de derechos, previendo un régimen de garantías también diferenciado para ambos (art. 17 para los derechos y libertades del Tit. II; y

18 Hay que advertir, antes de introducirnos en el comentario del articulado del texto constitucional, que éste ha experimentado, como consecuencia de las sucesivas revisiones, importantes cambios que afectan no sólo al contenido de las disposiciones modificadas sino también a su numeración. Es preciso tener siempre muy presente este dato ya que, de lo contrario, se pueden cometer (y de hecho se cometen) serios errores en la identificación de las distintas disposiciones constitucionales. Nosotros, en este trabajo, respetaremos la numeración que tienen en cada momento, después de cada revisión constitucional, que no coincide en muchos casos ni con la numeración originaria ni con la actual.

19 Sobre el régimen general de derechos y libertades en el texto originario de la Constitución de 1976, vid. Joao DE CASTRO MENDES: «Direitos, liberdades e garantias. Alguns aspectos gerais", en AA.VV.: Estudos sobre a Constituiçao, l, op. cit., pp. 93 y ss.; J. MIRANDA: "O regime des direitos, libertades e garantias", ibid., III, pp. 41 y ss.; del mismo autor, "Os direitos fundamentais na ordem constitucional portuguesa", Revista Española de Derecho constitucional (REDC), n. ${ }^{\circ} 18,1986, \mathrm{pp} .107$ y ss. 
art. 50 para los derechos económicos, sociales y culturales del Tit. III); esquema que refleja las nuevas tendencias constitucionales sobre la materia (que también tiene su reflejo en nuestra propia Constitución de 1978). Hay que subrayar, así mismo, la inusual amplitud que tiene la regulación de los derechos económicos, sociales y culturales (arts. 50-79), sin duda la más extensa y pormenorizada sobre esta materia en comparación con cualquier otro texto constitucional.

Cabe mencionar como rasgos distintivos del régimen constitucional de derechos y libertades, además de su marcado signo garantista, la concepción extensiva de los mismos, previendo expresamente su extensión "a cualesquiera otros que resulten de las normas aplicables de derecho internacional» (art. 16), su aplicabilidad directa (art. 18) o la referencia explícita al derecho de resistencia (art. 20). En cuanto a los derechos y libertades en particular, es preciso reseñar la novedosa alusión (en 1976) a la informática (art. 35) ${ }^{20}$, la constitucionalización de la igualdad civil de los cónyuges y de la no discriminación de los hijos extramatrimoniales (art. 36), que si bien hoy son admitidas de forma generalizada, en 1976 en Portugal (como también en España) constituían importantes novedades; así mismo, la referencia específica a los medios de comunicación social del Estado, a la confrontación en ellos de las diversas corrientes de opinión (art. 39) y al derecho de antena (art. 40); en el ámbito de las relaciones Iglesia-Estado, cuestión que en Portugal presenta especial relevancia, se establece la separación entre ambos (art. 41) y la aconfesionalidad de la enseñanza pública (art. 43).

Por lo que se refiere a los derechos y deberes económicos, sociales y culturales ${ }^{21}$, además de su inusual extensión (a la que ya se ha aludido anteriormente), cabe reseñar la peculiar forma de regulación de los derechos al trabajo y de los trabajadores, acompañados de las obligaciones del Estado en lo concerniente a los referidos derechos (arts. 51-54); así como la constitucionalización del derecho a crear comisiones de trabajadores (arts. 55 y 56), lo que no suele ser usual, además del derecho de asociación sindical, con una referencia expresa en este último caso a la independencia de los partidos políticos (arts. 57 y 58). Se constituciona-

20 Sobre este tema, en particular, vid. el comentario al texto originario del art. 35 de A. BARREIROS: "Informática, Liberdades e Privacidade, en Estudos sobre a Constituiçao, l, op. cit.; para un comentario sobre este mismo tema en la versión actual del art. 35, vid. P. RIBEIRO DA FARIA: "artigo 35», en AA.VV.: Constituiçao Portuguesa Anotada, l, Coimbra Ed., 2005, pp. 374 y ss.

21 Vid. M. A. VAZ: "O enquadramento jurídico-constitucional dos direitos económicos, sociais e culturais", en AA.VV. (A. VARELA, F. DO AMARAL, J. MIRANDA, J. J. Gomes CANotilho, orgs.): Ab Uno ad Omnes. 75 anos de Coimbra Editora, Coimbra, 1998, pp. 435 y ss. 
liza, así mismo, la propiedad privada, si bien admitiendo la posibilidad de expropiación sin indemnización en los supuestos previstos constitucionalmente (art. 62), lo que constituye una importante excepción, en relación con otros países, en el régimen constitucional de la propiedad.

En materia de derechos sociales se constitucionalizan con carácter universal, de acuerdo con los criterios propios del constitucionalismo social $^{22}$, los derechos a la Seguridad Social, a la salud, a la vivienda y al medio ambiente, dedicando a continuación una serie de disposiciones específicas referidas a la familia, la maternidad, la infancia, la juventud y los ancianos. Por último, los derechos culturales, y más concretamente el derecho a la educación, se vincula "al progreso de la sociedad democrática y socialista» (art. 73), asignando expresamente al Estado el deber de «modificar la enseñanza de modo que supere su función conservadora de la división social del trabajo" (art. 74). Finalmente, en lo que respecta al sistema de enseñanza, el Estado tendrá el deber de crear "una red de establecimientos oficiales de enseñanza que cubra las necesidades de toda la población"; en este marco, se admite la enseñanza privada, fiscalizada por el Estado y con carácter supletorio de la enseñanza pública (art. 75).

4. A la organización económica se dedica la Segunda parte de la Constitución, sin duda la que mayor disparidad presenta en relación con el modelo constitucional que rige en los países de Europa occidental. Tanto por la relevancia constitucional que se otorga al tema, al que se dedica íntegramente una de las cuatro partes que integran el texto constitucional, como por la amplitud con que es tratado (31 disposiciones, a las que habría que añadir bastantes más dispersas en otros pasajes constitucionales, tales como el Título ya referido sobre los derechos económicos, sociales y culturales, o algunas disposiciones preliminares relativas a los Principios fundamentales), nos hallamos ante un tratamiento de las cuestiones relativas a la Constitución económica que difiere radicalmente del que otros textos constitucionales de nuestro entorno dan a esta materia ${ }^{23}$.

${ }^{22}$ Vid. A. Ferreira: "Uma abordagem dos directos sociais", Fronteira, n. ${ }^{\circ}$, 1979, pp. 51 y ss.; así mismo, A. Colomer y J. L. LóPEZ: «Programa ideológico y eficacia jurídica de los derechos sociales", en AA.VV.: Perspectivas constitucionais, III, op. cit., pp. 307 y ss.

${ }^{23}$ Sobre la Constitución económica en su versión originaria, vid. G. D'OliveIRA MARTINS: "La Constitución económica portuguesa: del programa a la mediación», $R e-$ vista de Estudios Políticos, n. ${ }^{\text {os }}$ 60-61, op. cit., pp. 741 y ss.; así mismo, mi trabajo sobre el mismo tema "La revisión de la Constitución económica", en AA.VV.: La Constitución portuguesa..., op. cit., pp. 93 y ss. 
Llama la atención el radicalismo socializante que inspira al constituyente de 1976 así como los términos en que éste tiene plasmación; resulta muy expresivo al respecto el enunciado con el que se abre esta parte (segunda) de la Constitución al establecer el fundamento de la organización económico-social: "La organización económicosocial de la República portuguesa se basa en el desarrollo de las relaciones de producción socialistas, mediante la apropiación colectiva de los principales medios de producción... y el ejercicio del poder democrático de las clases trabajadoras" (art. 80). A partir de estas premisas, ajenas por completo al modelo constitucional económico euroccidental, el constituyente portugués de 1976 intenta diseñar un modelo distinto que introduce elementos provenientes del constitucionalismo de las democracias populares de los países del Este, plenamente vigente entonces, cuya caracterización resulta difícil pero, en cualquier caso, impregnado de un fuerte radicalismo socializante.

Se asigna al Estado un papel determinante en toda la actividad económica (art. 81: Misiones prioritarias del Estado), se constitucionalizan las nacionalizaciones, admitiendo la posibilidad de expropiación sin indemnización (art. 82) y se declaran conquistas irreversibles de las clases trabajadoras todas las nacionalizaciones efectuadas después del 25 de Abril de 1974. Se admite la iniciativa privada, pero en el marco previsto no sólo por la Constitución y la ley sino también por la planificación económica (art. 85.1), puntualizando además que mediante ley se determinarán "los sectores básicos en los que esté prohibida la actividad de las empresas privadas" (art. 85.2). Se dedica un Título específico (Tit. II) a la estructura de la propiedad de los medios de producción, distinguiendo entre el sector público, el cooperativo y el privado, asignando a este último una posición residual - «el sector privado estará constituido por los bienes y unidades de producción no comprendidos en los anteriores" (público y privado) (art. 89) - y otorgando expresamente una posición predominante al desarrollo de la propiedad social (art. 90) ${ }^{24}$.

Además de dedicar un Título específico al sistema financiero y fiscal (Tit. V), al igual que otros textos constitucionales, se dedican también sendos Títulos específicos a regular materias que no suelen ser objeto de tratamiento (al menos en la forma que lo hace la Constitución portuguesa de 1976) en el modelo constitucional euroccidental, tales como la planificación económica (Tit. III, arts. 91-95), la reforma agraria (Tit. IV,

${ }^{24}$ Un comentario más amplio sobre los principios de la organización económica en su versión originaria puede verse en J. BRAGA DE MACEDO: «Principios Gerais de Organizaçao Económica», en Estudos sobre a Constituiçao, l, 1977, op. cit., pp. 189 y ss. 
arts. 96-104) o, incluso, los circuitos comerciales (Tit. VI, arts. 109-110). Es en este ámbito donde se deja sentir con mayor nitidez la influencia de modelos constitucionales ajenos al euroccidental; en particular, del modelo propio de las democracias populares de los países del Este, entonces un importante referente a tener en cuenta que, sin duda, tuvo una influencia nada despreciable en el constituyente portugués de 1976.

Dadas las muy especiales características que presenta este pasaje relativo a la Constitución económica, no es de extrañar que haya sido el que mayores modificaciones ha experimentado en el ininterrumpido proceso de revisión constitucional que se ha desarrollado en Portugal en las tres últimas décadas. Aunque a lo largo de este trabajo se precisarán algunos de los principales cambios efectuados, puede adelantarse que el texto originario, elaborado por el constituyente de 1976 e impregnado de fuertes dosis de radicalismo socializante, resultaría hoy difícilmente reconocible ${ }^{25}$.

5. La organización institucional de la República portuguesa es el objeto de la Tercera Parte, la más extensa (166 arts.) del ya de por sí inusualmente extenso texto aprobado por el constituyente de 1976. En síntesis, puede afirmarse que en ella se diseña un modelo de organización institucional que responde, en líneas generales, a la forma de gobierno semipresidencial; si bien, es preciso puntualizar que se trata de un semipresidencialismo muy sui generis ${ }^{26}$, debido a la inserción en él, en especial en su versión originaria (1976) de instancias vinculadas directamente a la propia institución presidencial y ajenas por completo a la referida forma de gobierno semipresidencial; tal es el caso, señaladamente, del Consejo de la Revolución, del que más adelante nos ocuparemos (aunque es preciso adelantar que fue eliminado en la primera revisión constitucional, 1982).

A partir de esta inicial configuración de la organización institucional de acuerdo con un modelo semipresidencial sui generis, el sistema político portugués ha ido evolucionando en el sentido de una progresiva parlamentarización. Este proceso de homologación institucional se inicia ya con la primera revisión constitucional (1982), que suprime

${ }^{25}$ Es muy expresivo el título del trabajo que E. PAZ FERREIRA dedica a este tema: "A Constituiçao Económica de 1976. Que reste-t-il de nous amours?", en AA.VV.: Perspectivas Constitucionais, op. cit., pp. 383 y ss.

${ }^{26}$ Sobre este tema, vid., entre otros, V. CANAS: "A forma de governo semipresidencial e suas características. Alguns aspectos", Revista Jurídica, n. ${ }^{\circ} 1,1982$, pp. 89 y ss.; A. GonçAlves PereIRA: O semipresidencialismo em Portugal, Lisboa, 1984; R. MAchado HoRTA: "A Constituçao da República Portuguesa e o regime semipresidencial», en AA.VV.: Perspectivas Constitucionais, l, op. cit., pp. 515 y ss. 
una instancia tan extraña (desde una perspectiva constitucional) como la del Consejo de la Revolución, inicialmente prevista como la expresión institucional del Movimiento de las Fuerzas Armadas (MFA), cuyo fuerte protagonismo en el proceso constituyente explica esta anomalía institucional. Posteriormente, las sucesivas revisiones constitucionales, muy especialmente la cuarta (1997) y, sobre todo, la praxis institucional, han ido reconfigurando el modelo de organización institucional ${ }^{27}$ con rasgos progresivamente más alejados del originario semipresidencialismo sui generis y crecientemente más próximos al modelo parlamentario (si bien el Presidente de la República conserva aún algunas facultades que denotan su configuración inicial acorde con el atípico modelo semipresidencial originario).

Como en otros pasajes constitucionales ya reseñados, llama también la atención la forma, excesivamente detallista y pormenorizada, como se regula la organización institucional del Estado, lo que explica la inusual extensión del texto. Buena parte de las materias que son reguladas directamente por la Constitución bien podían haber sido objeto de regulación legislativa (al menos así ocurre en los textos constitucionales de otros países), evitando la sobrecarga reguladora del texto constitucional portugués y, en consecuencia, evitando la obligatoriedad de proceder a una amplia revisión constitucional (como ha ocurrido en Portugal) cada vez que era necesario modificar aspectos que no siempre tienen, por lo que se refiere a su contenido material, la suficiente entidad constitucional.

De acuerdo con esta orientación, la regulación que se hace de las principales instituciones del Estado - Presidencia (Tit. II, arts. 123-141), Asamblea de la Republica (Tit. IV, arts. 150-184), Gobierno (Tit. V, arts. 185-204), Tribunales (Tit. VI, arts. 205-226), Regiones Autónomas (Tit. VII, arts. 227-236) - contrasta con la de otros textos constitucionales ${ }^{28}$ por la

27 Sobre la evolución del peculiar modelo semipresidencialista portugués, vid. J. MIRANDA: "O sistema semipresidencial português entre 1976 y 1979", Revista da Faculdade de Direito da Universidade de Lisboa, 1984, pp. 193 y ss.; J. DuRAo BARROso: "Les conflits entre le Président portugais et la majorité parlamentaire de 1979 a 1983», en AA.VV. (M. DuVERGER, org.): Les régimes semi-présidentiels, Paris, 1986, pp. 237 y ss.; A. MoREIRA: «El régimen: Presidencialismo del Primer Ministro», Revista de Estudios Políticos, n. ${ }^{\text {s }} 60-61$, op. cit., pp. 21 y ss.

28 Desde una perspectiva comparativa, en relación con otros regímenes semipresidenciales, vid. C. BLANCO DE MORAIS: "Le metamorfosi dei semipresidenzialismo portoghese", en AA.VV. (L. Pegoraro y A. RinelLA, org.): Semipresidenzialismi, Padua, 1997, pp. 125 y ss. Así mismo, desde una perspectiva comparativa circunscrita a Portugal y España, A. VITORINO: "O sistema de governo na Constituçao portuguesa de 1976 e na Constituiçao española de $1976 »$, Revista Jurídica, n. ${ }^{\circ} 3,1984$, pp. 33 y ss. 
forma acusadamente minuciosa en que son objeto de tratamiento. Así mismo, son objeto de la atención del constituyente de 1976 materias que o bien no lo son en otros textos constitucionales -el caso más llamativo es el del ya referido Consejo de la Revolución (Tit. III, arts. 142149) - o lo son de forma muy sucinta. Tal es el caso de las instituciones municipales, a las que la Constitución portuguesa dedica nada menos que treinta disposiciones, agrupadas en un Título específico (Tit. VIII, arts. 237-266); de la Administración Pública, a la que también se dedica un Título íntegro (Tit. IX ); o, finalmente, las FF.AA., objeto de un Título (X) dedicado exclusivamente a ellas en el que, además de las funciones propias de las FF.AA., se las asigna también funciones un tanto dudosas desde el punto de vista constitucional, relacionadas con la garantía del funcionamiento regular de las instituciones democráticas y el cumplimiento de la Constitución (art. 273.3).

6. La cuarta y última parte, la más breve (arts. 277-291), en contraste con la desmesurada extensión de las tres partes precedentes, se dedica a la Garantía y Revisión de la Constitución. Ciñéndonos a las garantías (arts. 277-285) —de la revisión nos ocuparemos más detenidamente a continuación- lo primero que es preciso reseñar, al igual que ya se ha reiterado en otras ocasiones, es la forma totalmente atípica como se articulan éstas. Independientemente de la novedad que puedan suponer las figuras del control preventivo de constituiconalidad (art. 277) o de la inconstitucionalidad por omisión (art. 279), a añadir a las más comunes del control de constitucionalidad de las normas aprobadas (art. 280) o del control judicial de insconstitucionalidad (art. 282), lo que más llama la atención es el papel que juega en esta materia un órgano como el Consejo de la Revolución, que es el que realmente ejerce el control de constitucionalidad.

De acuerdo con las propias previsiones constitucionales, el Consejo de la Revolución, depositario de la legitimidad revolucionaria del 25 de Abril, se configura como el "garante de la observancia de la Constitución" (art. 146); y, como tal, tiene atribuida expresa y directamente por la Constitución las funciones de pronunciarse, bien por iniciativa propia o a instancias del Presidente de la República, sobre la constitucionalidad de cualquier texto legal, antes de su promulgación; apreciar la posible inconstitucionalidad de los textos ya publicados; e, incluso, velar por la adopción de las medidas necesarias para el cumplimiento de las normas constitucionales, formulando, en caso de su incumplimiento por omisión, las recomendaciones pertinentes para ello (art. 146). La atipicidad de este modelo de control de constitucionalidad se hace más llamativa dado el carácter íntegramente militar del órgano encargado de cumplir estas funciones - el Consejo de la Revolución-que 
constituye la expresión orgánica del Movimiento de la Fuerzas Armadas $(M F A)^{29}$.

Junto al Consejo de la Revolución se instituye la Comisión Constitucional como órgano de carácter jurídico, auxiliar de aquél, al que compete emitir los preceptivos dictámenes tanto sobre los textos a examinar por el Consejo de la Revolución como sobre la eventual vulneración por omisión de las normas constitucionales; o, en su caso, pronunciarse sobre las cuestiones de inconstitucionalidad planteadas por los Tribunales al aplicar la ley (art. 284). Se trata, como puede observarse, de un órgano vinculado al Consejo de la Revolución, con funciones de asistencia a éste en el ámbito específico jurídico-constitucional $^{30}$. En cualquier caso, es preciso reseñar el carácter auxiliar y subordinado en relación con el Consejo de la Revolución, lo que se pone de manifiesto con claridad en la previsión constitucional de que su organización, funcionamiento y procedimiento — de la Comisión Constitucional- serán regulados por aquél (art. 285).

Aunque más adelante nos ocuparemos de ello, es preciso adelantar que esta extraña y atípica forma de ejercer el control de constitucionalidad fue rápidamente sustituida por otra más acorde con el modelo típico, basado en la jurisdicción del Tribunal Constitucional. Este órgano será creado por la primera revisión (1982), coincidiendo con la supresión del Consejo de la Revolución, estableciéndose así un sistema homologable de control de constitucionalidad ${ }^{31}$.

\section{LA REVISIÓN CONSTITUCIONAL. CARACTERÍSTICAS GENERALES Y RASGOS DISTINTIVOS DEL PROCESO DE REVISIÓN PORTUGUÉS}

La Revisión constitucional presenta también notables singularidades tanto en lo que concierne a los aspectos procedimentales y temporales como por lo que se refiere a los contenidos y límites materiales. Si bien

29 Vid. A. Ribeiro Mendes: «O Conselho da Revoluçao e a Comissao Constitucional na fiscalizaçao da constitucionalidade das leis (1976-1983)", en AA.VV. (M. B. CoELHO, org.): Portugal. O sistema político e constitucional, Lisboa, 1989, pp. 925 y ss.

30 Vid. M. Lobo Antunes: "A fiscalizaçao da constitucionalidade das leis no primeiro período constitucional: a Comissao Constitucional», Análise Social, n. ${ }^{\text {os }} 81-82$, 1984, pp. 309 y ss.

31 Vid. L. Nunes de AlmeIdA: «Da politizaçao da Justiça à justicializaçao da política. Do Conselho da Revoluçao ao Tribunal Constitucional», en AA.VV. (J. J. GomeS CAnotilho, org.): 20 anos da Constituiçao de 1976, pp. 277 y ss. 
toda la Constitución, en su conjunto, como así mismo cada una de sus partes, en particular, presentan rasgos distintivos acusadamente singulares en relación con la experiencia constitucional comparada, tal y como se ha venido reseñando en los párrafos precedentes, esta singularidad resulta especialmente determinante en el ámbito de la revisión constitucional $^{32}$. En este caso, los términos en que se prevé la revisión constitucional no sólo son un elemento distintivo más sino que van a condicionar de forma decisiva el proceso de revisión constitucional $y$, en definitiva, la propia evolución constitucional portuguesa en las tres últimas décadas.

1. Por lo que se refiere al procedimiento de revisión constitucional hay que reseñar como característica distintiva la exclusividad parlamentaria en todo el proceso de revisión. No sólo la aprobación final de la ley de revisión corresponde a la Asamblea de la República, lo que suele ser común en la experiencia comparada, sino que la iniciativa y toda la tramitación se reserva, en exclusiva, a la Asamblea de la República; lo que constituye un rasgo distintivo del procedimiento de revisión portugués. Es preciso puntualizar que se trata de una exclusividad con carácter absoluto ya que ninguna otra instancia puede intervenir en el proceso, incluido el Gobierno, al que en la experiencia constitucional comparada se le suele admitir que ejerza la iniciativa de la revisión; así mismo, tampoco se admite la iniciativa legislativa popular en esta materia ni la intervención de órgano alguno de naturaleza extraparlamen$\operatorname{taria}^{33}$.

La exclusividad de la Asamblea de la República en la tramitación de la revisión se extiende a la conclusión de ésta, viniendo obligado el Presidente de la República a promulgar inexcusablemente la ley de revisión (así como el nuevo texto constitucional revisado) en los términos aprobados por la Asamblea de la República (art. 286.2). Finalmente, y ésta es una diferencia importante, no cabe la posibilidad de someter a referéndum, bien a instancia del Presidente de la República o de un grupo de diputados (como frecuentemente se prevé en otros textos constitucio-

32 Sobre este tema, con carácter general, vid. J. MAgALHAES: Dicionário da Revisao Constitucional, Lisboa, 2004 (3. ${ }^{a}$ edic.).

${ }^{33}$ Sobre la exclusividad parlamentaria en el proceso de revisión constitucional en Portugal, vid. F. PAULO GonçALVES: "La problemática de la revisión constitucional», en AA.VV.: La Constitución portuguesa, op. cit., pp. 263 y ss.

34 Excluyendo Alemania, que no lo contempla en ningún caso, el referéndum constitucional está previsto expresamente, entre otros países próximos, en Francia (art. 89), en Italia (art. 138) y en España (arts. 167 y 168). Vid. al respecto M. HoNORATI: II referendum nella procedura di revisione costituzionali, Milano, 1982. 
nales) ${ }^{34}$, la ley de revisión aprobada por la Asamblea de la República.

2. Por lo que se refiere al contenido material de la revisión, el constituyente portugués de 1976 acota ésta mediante la enumeración de un amplio y detallado listado (quince apartados) de límites materiales (art. 290) que, por su extensión y, así mismo por el contenido de alguno de ellos, resulta difícil encontrar una disposición equiparable en el constitucionalismo comparado. Además del profuso listado de materias vedadas al legislador de revisión, hay que llamar la atención sobre el carácter heterogéneo de las materias integrantes del referido listado, en el que se incluyen desde principios básicos y fundamentales del sistema en su conjunto - forma republicana de gobierno, garantías de los derechos y libertades, separación de poderes, independencia de los Tribunales- hasta opciones político-sociales producto de la coyuntura del periodo constituyente - principio de apropiación colectiva de los medios de producción o la planificación económica- pasando por formulaciones imprecisas de difícil concreción en términos jurídicos - participación de las organizaciones populares básicas en el ejercicio de la administración local-.

Debido a ello, los límites materiales fijados en la disposición que comentamos $^{35}$ no fueron respetados en las sucesivas revisiones constitucionales realizadas posteriormente. En particular, fueron las referencias de carácter económico y social las menos respetadas, bien mediante la supresión de los apartados que hacían referencia a esos límites (así, la apropiación colectiva de los medios de producción, la planificación económica, la participación de las organizaciones populares básicas en la administración local); o bien modificando en profundidad o, a veces, suprimiendo directamente las disposiciones constitucionales originarias en materia económica y social.

Dado el continuo proceso de revisión que ha experimentado la Constitución portuguesa, no es de extrañar que sea esta disposición constitucional, precisamente por tratar sobre el tema e imponer además numerosos límites a la revisión, la que ha suscitado una mayor y

35 Vid. G. VAGLI: «Nasita, evoluzione e significato dei limiti materiali espressi di revisione nella Costituzione portoghese", Quaderni Costituzionali, n. ${ }^{\circ}$ 1-1998, pp. 101 y ss.

36 Vid. A. DE ALMEIDA: "Los límites materiales de la revisión constitucional a la luz de la doctrina y del sentido común", Revista de Estudios Políticos, n. ${ }^{\circ}$ 60-61 (monográfico), op. cit., pp. 953 y ss.; así mismo, en la misma publicación, Rui MACHETE: "Los principios estructurantes de la Constitución y la revisión constitucional en Portugal», op. cit., pp. 913 y ss. 
más intensa polémica tanto en círculos doctrinales como políticos ${ }^{36}$. Sin entrar aquí en ella, lo que desbordaría ampliamente el objeto de estas líneas, sí es preciso reseñar, una vez más, la singularidad que supone la forma como se regulan los profusos límites materiales a la revisión y el desbordamiento de que han sido objeto reiteradamente en las sucesivas revisiones constitucionales que se han venido produciendo de forma ininterrumpida en Portugal durante las tres últimas décadas.

3. Otro de los rasgos distintivos de la revisión constitucional en Portugal hace referencia a factores de carácter temporal. A diferencia de otros textos constitucionales, que no suelen contener previsiones sobre el momento en que han de realizarse las revisiones constitucionales, el constituyente de 1976 prevé expresamente, en una disposición dedicada específicamente a "la primera revisión» (art. 286) que «en la segunda legislatura la Asamblea de la República tendrá poderes de revisión constitucional». Así mismo, prevé también que las revisiones subsiguientes (que son objeto de otra disposición específica, art. 287) podrán ser realizadas transcurridos cinco años desde la publicación de la anterior ley de revisión. Esta previsión expresa de revisiones en los periodos (II legislatura) y plazos (cinco años) reseñados no impide que la Asamblea de la República pueda «asumir, en cualquier momento, poderes de revisión constitucional si así lo acuerda por mayoría de cuatro quintos de los diputados en el ejercicio activo de sus funciones" (art. 287.2).

Esta inusual vocación revisionista tiene sus raíces en los propios antecedentes constitucionales históricos sobre la materia, que a diferencia de otros textos constitucionales coetáneos contemplaban también expresamente la revisión periódica de la Constitución ${ }^{37}$. En cualquier caso, no cabe duda de que la previsión expresa, en los términos reseñados, de la propia revisión constitucional, es un factor que invita a la Asamblea de la República a su realización. Ello explica, en buena medida, el continuado proceso de revisión constitucional que ha tenido lugar en Portugal desde la II legislatura (1980-1983), que como ya hemos señalado venía obligada constitucionalmente a asumir poderes de revisión, hasta la actualidad (siete revisiones constitucionales entre 1982 y 2005).

37 La «Constitución» de 1933 (art. 137) preveía la revisión constitucional cada diez años, pudiendose anticipar si así lo decidía una mayoría cualificada de dos tercios de los diputados; sistema muy parecido al actual. Sobre la revisión en el constitucionalismo histórico portugués —textos de 1822, 1826, 1911- vid. F. PAULO GONÇALVES: "La problemática de la revisión constitucional», op. cit., p. 268. 
4. Las sucesivas revisiones constitucionales han afectado también a las disposiciones relativas a la propia revisión constitucional, introduciendo nuevas modalidades de ésta. Además de las ya reseñadas sobre la modificación de los límites materiales de la revisión constitucional (ver supra) y de la reordenación y renumeración de las disposiciones sobre la materia (arts. 286-291 en la numeración originaria) ${ }^{38}$, la tercera revisión (1992) introduce la figura de la revisión extraordinaria, distinguiendo así entre esta nueva modalidad de revisión y las ordinarias.

En realidad, se trata de formalizar explícitamente, bajo la doble modalidad referida - ordinaria y extraordinaria - lo que ya estaba implícito en la formulación originaria de la revisión constitucional. En síntesis, además de la revisión ordinaria de la Constitución, que sólo podrá hacerse «transcurridos cinco años desde la publicación de la última ley de revisión ordinaria" (nueva redacción del art. 284.1 tras la revisión de 1992), la Asamblea de la República podrá, en cualquier momento (es decir, sin tener que esperar el plazo de cinco años), proceder a efectuar una revisión, con carácter extraordinario, si así lo acuerda "una mayoría de cuatro quintos de los diputados en el ejercicio de sus funciones". En ambos casos - revisión ordinaria y extraordinaria- la mayoría exigida para aprobar finalmente la revisión es la misma: "dos tercios de los diputados en el ejercicio efectivo de sus funciones". Así pues, el carácter extraordinario ${ }^{39}$ (u ordinario) de la revisión no hace referencia, como en otros ordenamientos constitucionales (entre ellos, el español) al contenido o a las mayorías exigidas sino tan sólo al momento en que se hace la revisión.

Tres de las siete revisiones constitucionales han tenido carácter extraordinario: la tercera (1992), la quinta (2001) y la séptima (2005); otras tres han tenido carácter ordinario: la segunda (1989), la cuarta (1997) y la sexta (2004). Por último, la primera (1982) tenía carácter obligado puesto que venía exigida por la propia Constitución, al atribuir expresamente (art. 286.1) a la Asamblea de la República poderes de revisión constitucional en la II legislatura (1980-1983).

${ }^{38}$ Es preciso reiterar la advertencia ya hecha anteriormente (ver supra, nota $\mathrm{n} .^{\circ}$ 18) sobre el cambio en la numeración de las disposiciones constitucionales tras las sucesivas revisiones constitucionales.

39 Sobre las peculiaridades procedimentales del proceso de revisión extraordinaria, vid. A. SouSA PINHEIRO: "Prazos para presentaçao dos projectos de revisao constitucional em processo de revisao extraordinaria", Revista Jurídica da AAFDL, n. ${ }^{\text {os }} 18-19,1995$. 
5. Si bien la forma en que el constituyente de 1976 contempla la revisión del texto por él aprobado puede facilitar ésta, o incluso inducir a su realización, el factor determinante del intenso y prolongado proceso de revisión constitucional seguido en Portugal desde poco después de que entrase en vigor el texto constitucional de 1976 radica, ante todo, en las propias características de éste. Como se ha visto en los párrafos precedentes, se trata de un documento que, a pesar de encuadrarse en el espacio político-constitucional euroccidental, es completamente atípico, con elementos manifiestamente discordantes, en muchos casos, en relación con el modelo constitucional que, aunque con distintas variantes, rige en Europa occidental.

Ello era producto, como también se ha indicado ya, de la excepcional coyuntura político-militar de la revolución de los claveles y del fuerte influjo que sobre el constituyente de 1976 ejercieron las corrientes vinculadas al radicalismo socializante que impregnaba en ese momento las posiciones del Movimiento de las Fuerzas Armadas (MFA). Por otra parte, el constituyente de 1976 introduce, sobre la base del esquema propio del constitucionalismo social de la década de los setenta, elementos ajenos al modelo constitucional euroccidental; en particular, elementos provenientes del constitucionalismo de las democracias populares de los entonces denominados países del Este - hoy desaparecido pero en aquélla época vigente y con una influencia nada despreciable, como lo muestra el propio caso de Portugal-e, incluso, algunas manifestaciones del constitucionalismo de la descolonización ${ }^{40}$ (esto último debido a que es precisamente en el marco del proceso constituyente cuando se produce la ruptura con la condición de país colonizador que ostentaba Portugal hasta ese momento).

En este contexto, en el que es preciso encuadrar la obra del constituyente de 1976, es lógico que se plantease con fuerza la necesidad de proceder a la revisión constitucional (a lo que, además, incitaban las propias previsiones constitucionales sobre la revisión, ver supra). Por otra parte, se alejaba en el tiempo la excepcionalidad del periodo fundacional inmediatamente posterior a la revolución de los claveles, sustituido progresivamente por la normalidad político-institucional en el nuevo marco constitucional. Y, así mismo, dejaban de ser modelos de referencia tanto las democracias populares de los países del Este ${ }^{41}$

40 Vid. G. Vergottinl: Le origini della Seconda Repubblica Portoghese, op. cit. Así mismo, P. LUCAS VeRdU: "Dimensión axiológica de la Constitución portuguesa", op. cit.

41 Sobre todo desde finales de la década de los ochenta, a partir de la caída del muro de Berlín (1989) y de la disolución de la Unión Soviética (1991). 
como, más aún, en un país como Portugal ubicado geográfica y políticamente en la Europa en proceso de integración, los referentes anticoIoniales propios de los países del Tercer Mundo.

6. Las revisiones constitucionales realizadas en Portugal en las tres últimas décadas presentan una serie de características distintivas que singularizan el proceso de revisión en su conjunto. El primer rasgo distintivo a reseñar es la extensión y amplitud de la revisión efectuada, que afecta a la práctica totalidad del texto constitucional, lo que puede observarse con la simple lectura del texto originario de 1976 y el actualmente vigente ${ }^{42}$. Puede afirmarse que, salvo en los casos en que se ha adoptado una nueva Constitución (aunque en este supuesto no cabe hablar con propiedad de revisión constitucional) ${ }^{43}$ se trata del proceso de revisión más amplio; al menos por lo que refiere a las Constituciones europeas en estas tres últimas décadas (y probablemente también en relación con cualquier otra Constitución).

El ámbito de la revisión se extiende a todas las Partes en que se divide el texto constitucional; y dentro de cada una de ellas, afecta a la práctica totalidad de los Títulos, Capítulos y Secciones en que se subdividen; lo que da cuenta del carácter global y general que ha tenido la actividad revisora del legislador constitucional. Por otra parte, no es nada infrecuente que una misma disposición constitucional sea objeto de revisión de forma reiterada (así, por ejemplo, las relativas a la Constitución económica), lo que permite detectar la orientación que sigue la evolución constitucional, más allá de cada una de las revisiones consideradas por separado.

Si bien las distintas revisiones difieren sustancialmente en cuanto a su amplitud, puede afirmarse que la vocación revisora del legislador constitucional no sólo se extiende a la totalidad del texto constitucional sino que llega incluso a penetrar en el ámbito protegido por la cláusulas que delimitan los límites materiales de la revisión, lo que no deja de ser una reseñable peculiaridad de la revisión constitucional portuguesa por lo que se refiere a la ampliación del propio ámbito (de revisión) pre-

42 Existe versión en castellano íntegra del texto originario (1976), en M. DARANAS: Constituciones Europeas, II, Editora Nacional, Madrid, 1979, pp. 1523-1648. El texto actual, tras la última revisión constitucional (Agosto 2005), puede verse en http://www.parlamento.pt

${ }^{43}$ Además de los países surgidos de la desmembración de la antigua U.R.S.S. y de los países de Europa central y oriental (P.E.C.O.), que han adoptado nuevos textos constitucionales durante la década de los noventa, cabe mencionar, en Europa occidental, los casos de Bélgica (1994), Suiza (1999) y Finlandia. 
visto inicialmente. A pesar de la polémica doctrinal suscitada al respecto ${ }^{44}$, la praxis del legislador constitucional ha despejado, a su favor, el dilema que pudiera existir en torno al ámbito excluido de la revisión, mediante la modificación de los propios límites de ésta.

De las siete revisiones constitucionales realizadas, tres de ellas tienen carácter general y global: la primera (1982), la segunda (1989) y la cuarta (1997); otras tres tienen un objetivo limitado, relacionado principalmente con el marco europeo e internacional: la tercera (1992), la quinta (2001) y la séptima (2005); por último, la sexta revisión (2004), aunque originariamente se planteó con carácter limitado, sobrepasó en el curso de su tramitación esta limitación, extendiéndose a otras cuestiones no previstas inicialmente.

7. Otra de las características distintivas a reseñar es la continuidad que ofrece el proceso de revisión constitucional en Portugal. Casi todas las legislaturas de la Asamblea de la República, a partir de la segunda (iniciada en 1980 y a la que la propia Constitución, en su redacción originaria, atribuía expresamente «poderes de revisión constitucional" (art. 286)), han protagonizado sucesivas revisiones: dos en la década de los ochenta (1982 y 1989), otras dos en la de los noventa (1992 y 1997) y otras tres en la actual década en curso (2001, 2004 y 2005). Interesa llamar la atención sobre la regularidad de la cadencia temporal de las revisiones, lo que denota que no están vinculadas a una coyuntura política determinada ni a mayorías parlamentarias de uno u otro signo.

En este sentido, puede afirmarse que la revisión constitucional en Portugal, a diferencia de otros países (y entre ellos, de forma muy especial, el nuestro), constituye un elemento estructural de su propia cultura constitucional. A ello contribuye también la propia tradición histórica del constitucionalismo portugués (Constitución de 1911 y texto de 1933), que también a diferencia de otros países ha contemplado la revisión constitucional como un mecanismo no sólo permitido sino que era aconsejable utilizar de forma periódica ${ }^{45}$. Enlazando con estos antecedentes históricos, tanto el constituyente de 1976 como, poste-

${ }_{44}$ Vid. M. N. Brito: A Constituiçao Constituinte. Ensaio sobre o poder de revisao, Coimbra, 2000; I. G. Martins: "Cláusulas Pétreas», en AA.VV. (J. MiRANDA, org.): Perspectivas Constitucionais, op. cit., pp. 195 y ss.

45 Art. 137 de la "Constitución" de 1933; art. 82 de la Constitución de 1911; sobre la revisión constitucional en el constitucionalismo histórico portugués, vid. el ya mencionado trabajo de F. PAULO GONÇALVES: "La problemática de la revisión constitucional», op. cit., p. 268. 
riormente, los sucesivos legisladores constitucionales, han incorporado a su acervo la cultura de la revisión constitucional, haciendo uso de ella de forma continuada.

Como se desprende de la continuada praxis revisionista del legislador constitucional portugués, no se trata de recurrir con carácter excepcional a la revisión constitucional sino que, por el contrario, ésta es expresión de la normalidad constitucional. Contrasta fuertemente esta concepción con la que suele ser predominante en otros países, en los que habitualmente se recurre a la revisión constitucional sólo de forma ocasional o excepcional ${ }^{46}$. En cualquier caso, el carácter continuado y permanente del proceso de revisión experimentado por la Constitución portuguesa desde el mismo momento de su aprobación (recuérdese que ya se preveía expresamente en el texto inicial de 1976 una primera revisión en la II legislatura) es un dato distintivo de la vida constitucional portuguesa. De forma más acusada que en otros países, la revisión constitucional, continuada y permanente, está estrechamente vinculada al desarrollo del proceso político portugués $y$, asimismo, es un elemento imprescindible para conocer la evolución política portuguesa durante las tres últimas décadas.

8. En sintonía con el carácter acusadamente ideológico que presenta el texto constitucional originario aprobado en 1976, las sucesivas revisiones de éste van a presentar también una fuerte componente ideológica, aunque ahora de signo inverso a la originaria. No se trata de meros reajustes técnicos ni tampoco solamente de una adaptación a las nuevas situaciones que van surgiendo y que exigen introducir nuevas formulaciones constitucionales (aun siendo importante la obra del legislador constitucional en este terreno). Pero lo que interesa subrayar aquí, por constituir uno de los principales rasgos distintivos del proceso de revisión constitucional portugués, es el acusado sesgo ideológico que le impregna; o para ser más precisos: el proceso de rectificación ideológica que se va a producir, a través de las sucesivas revisiones constitucionales realizadas a partir de 1982.

46 Era el caso, entre los países más próximos, de Francia e Italia (no así de Alemania), que hasta la pasada década de los noventa sólo se planteaban la revisión constitucional de forma esporádica y en muy contadas ocasiones. Sin embargo, desde el inicio de la década de los noventa las revisiones constitucionales se han venido sucediendo en ambos países de forma más habitual (como se ha venido haciendo en Alemania desde los años cincuenta). El caso más extremo de recelo a la revisión constitucional es, sin duda, España, donde no ya su realización sino su simple planteamiento provoca profundas crisis políticas. 
La obra del legislador constitucional ha de ser encuadrada, por lo que se refiere a los aspectos ideológicos, en el marco de la reacción frente a la carga ideológica que, a su vez, se explicitaba en la obra del constituyente de 1976, surgido de la revolución de los claveles ${ }^{47}$. El alejamiento progresivo en el tiempo de la excepcional coyuntura constituyente inducía a la reformulación de los pronunciamientos ideológicos iniciales, producto en gran medida de la efervescencia política e ideológica que se vivía en ése momento. Por otra parte, a partir de la década de los ochenta (periodo en el que se inicia la revisión constitucional en Portugal) cambia radicalmente el signo de las tendencias ideológicas dominantes, en detrimento de las posiciones socializantes que habían inspirado el texto originario de 1976 y a favor de las de orientación neoliberal, lo que lógicamente va a influir decisivamente en las sucesivas revisiones constitucionales.

En este contexto, interno y externo, el proceso de revisión constitucional iniciado en Portugal a partir de la década de los ochenta va a tener como hilo conductor la homologación del atípico modelo constitucional portugués en relación con el que rige en los países de su entorno geográfico y político; lo que además venía exigido por el proceso en curso de integración de Portugal en la Europa comunitaria y en la UE ${ }^{48}$. Por otra parte, no hay que olvidar que, en su versión originaria de 1976, la Constitución portuguesa es, precisamente a causa de sus formulaciones ideológicas, la que presenta un grado mayor de disparidad con el modelo constitucional europeo, lo que lógicamente inducía a acometer un proceso tendente a restablecer la sintonía constitucional entre Portugal y el resto de los países europeos.

Todo ello obligaba al legislador constitucional a abordar la tarea de homologación constitucional mediante la supresión de las formulaciones más marcadamente ideológicas del texto originario y su sustitución por otras más acordes con las nuevas tendencias dominantes a partir de la década de los ochenta. A esta orientación va a responder el proceso de revisión emprendido por el legislador constitucional en este pe-

47 Es muy ilustrativa la pregunta que servía de título a un difundido opúsculo de la época de uno de los protagonistas más significados durante el periodo constituyente, Melo Antunes: Portugal, República socialista?, Lisboa, 1975.

${ }^{48}$ Portugal se integra, juntamente con España, en la Europa comunitaria (entonces formada básicamente por la Comunidad Económica Europea, CEE) en 1986. Poco después (1987) suscribe el Acta Única Europea y, a continuación, el Tratado de la Unión Europea (Maastricht, 1992). Dadas las peculiares características del texto constitucional portugués originario, resultaba obligado realizar importantes ajustes constitucionales. 
riodo; y muy especialmente las dos primeras revisiones, de 1982 y 1989 , en las que con mayor claridad se plasma el proceso de rectificación ideológica en el plano constitucional.

Otra de las características distintivas del texto constitucional de 1976, que no es ajena al marcado acento ideológico al que nos hemos referido, es su acusado carácter programático ${ }^{49}$. Ello incide directamente sobre la revisión constitucional ya que son los textos de estas características - programáticos - los más proclives a la revisión, al ser las formulaciones programáticas las más susceptibles de modificación de acuerdo con el signo, igualmente cambiante, de las sucesivas mayorías parlamentarias. En este sentido, las revisiones constitucionales portuguesas no resultan ajenas al acusado carácter programático que presenta el texto constitucional portugués, sobre todo en su versión originaria de 1976.

Se trataba, además, de un contenido programático que era la expresión del programa del Movimiento de las Fuerzas Armadas (MFA) tras la revolución de los claveles y durante el periodo constituyente ${ }^{50}$; programa que dista mucho del de los gobiernos y mayorías parlamentarias que se suceden a partir de la década de los ochenta, lo que da lugar inevitablemente a la revisión constitucional de tales formulaciones programáticas. Estas eran especialmente intensas (y dispares en relación con el modelo constitucional euroccidental) en materia económica y social, lo que explica que sean precisamente estas materias las más afectadas por la revisión constitucional.

Por otra parte, conviene tener presente que todos los textos constitucionales de carácter programático, y muy particularmente los de inspiración marxista de las democracias populares de los países del Este (que como ya se ha reseñado ejercieron un importante influjo sobre el constituyente portugués de 1976), son especialmente proclives a la revisión constitucional ${ }^{51}$. Es en este marco en el que es preciso encuadrar las sucesivas, continuadas y extensas revisiones llevadas a cabo por el legislador constitucional en las tres últimas décadas.

49 Todos los autores, tanto portugueses como de otros países, coinciden en resaltar el carácter acusadamente programático de la Constitución portuguesa, sobre todo en su versión originaria de 1976. Vid., entre otros, J. J. GoMES CANOTILHO: Direito Constitucional e Teoría da Constituiçao, op. cit., p. 217.

50 Sobre los pactos entre el MFA y los partidos políticos en el periodo constituyente, vid. J. Medeiros Ferreira: Portugal en transición, Fondo de Cultura Económica, Mexico, 2000, pp. 253, 263 y 284.

51 Cfr. P. BISCARETTI: Introducción al Derecho Constitucional Comparado, op. cit., pp. 130 y 542. 
9. Una última característica a reseñar del proceso de revisión constitucional es el elevado grado de respaldo político que ha tenido, no sólo en términos cuantitativos ( $n .^{\circ}$ de votos en la Asamblea de la República) sino también cualitativamente, atendiendo a los apoyos que ha cosechado entre las distintas formaciones políticas. Si bien la propia Constitución preveía una mayoría cualificada cifrada en dos tercios de los diputados que integran la Asamblea de la República (que se eleva a cuatro quintos en el supuesto de asumir facultades de revisión extraordinaria) para aprobar cualquier revisión constitucional, lo que aquí interesa subrayar, más que la suma numérica de votos que alcancen las mayorías exigidas, es el hecho de la concurrencia de fuerzas políticas de distinto signo para sacar adelante las sucesivas revisiones constitucionales $^{42}$.

En este sentido, es preciso constatar que todas y cada una de las revisiones constitucionales han contado con el apoyo de las dos principales formaciones políticas portuguesas -Partido Socialdemócrata y Partido Socialista - que han protagonizado sucesivamente la alternancia en el Gobierno (y en la oposición) a lo largo de estas tres últimas décadas. Se cumplía así, más allá de las mayorías cuantitativas formalmente exigidas, un requisito que es conveniente tener en cuenta en todo proceso de revisión constitucional como es que ésta no sea el producto de una mayoría ocasional, por elevada que pueda ser en un momento determinado, de un solo partido (o de éste y algún aliado menor) sino producto de un acuerdo que abarque, por lo menos, a las principales formaciones políticas del Gobierno y de la oposición.

Junto a las dos formaciones políticas mayoritarias reseñadas -Partido Socialista y Partido Socialdemócrata - las revisiones constitucionales han contado también con el apoyo, en casi todas las ocasiones, del CDS-PP, formación ubicada a la derecha del PSD, con el que ha compartido coalición de gobierno en repetidas ocasiones. En posiciones contrapuestas, el Partido Comunista Portugués (PCP), que fue uno de los principales impulsores de la Constitución de 1976, se ha opuesto a todas las revisiones constitucionales, posición compartida únicamente por los verdes y por otros grupos de la izquierda radical. En

52 Todos los autores coinciden en subrayar el carácter compromissorio de la Constitución portuguesa. Vid., entre otros, J. MiRAndA: Constituiçao Portuguesa Anotada, I, Coimbra Ed., 2005, p. 13. Este carácter compromissorio ha sido mayoritariamente mantenido en las revisiones constitucionales, si bien con la ausencia de algunas formaciones que, como el Partido Comunista Portugués, fue un elemento muy activo en el compromiso constitucional originario de 1976 y que luego no respaldó las sucesivas revisiones constitucionales realizadas. 
cualquier caso, la oposición de estos grupos no ha logrado impedir ninguna de las revisiones realizadas hasta el momento.

\section{LA RECTIFICACIÓN CONSTITUCIONAL. LAS REVISIONES DE 1982 Y 1989}

Las dos primeras revisiones constitucionales (1982 y 1989) tienen como objetivo principal la rectificación de la obra del constituyente de 1976, surgido de la revolución de los claveles. Si bien ambas revisiones son extraordinariamente amplias, afectando a la casi totalidad del texto constitucional originario ${ }^{53}$, el eje central de la obra del legislador constitucional de 1982 y 1989 gira en torno a las formulaciones más marcadamente ideológicas, a algunos aspectos de la organización institucional y, así mismo, a la re-regulación de las materias de contenido económico y social. Todas estas cuestiones van a ser objeto de una profunda rectificación que introduce cambios sustanciales en el sistema constitucional portugués cuando éste apenas acaba de cumplir su primera década de vida.

Aunque ambas revisiones forman parte de un mismo proceso de rectificación constitucional, conviene distinguir entre ambas por los efectos derivados de cada una de ellas en los planos ideológico, orgánico-institucional y económico-social. En este sentido, puede afirmarse que la primera revisión (1982) tiene como objeto prioritario la rectificación institucional ${ }^{54}$, en particular de aquellos órganos más estrechamente vinculados al MFA (así, el Consejo de la Revolución), mientras que la segunda $(1989)^{55}$ se ocupa preferentemente de completar la rec-

${ }^{53}$ Lei Constitucional 1/1982 (Diário da República, I Serie A, n. ${ }^{\circ} 227$, de 30 de Septiembre de 1982), y Lei Constitucional 1/1989 (Diário da República, I Serie A, n. ${ }^{\circ} 155$, de 8 de Julio de 1989). Existe una versión integrada, en castellano, del texto constitucional resultante de ambas revisiones de 1982 y 1989, en Boletín de Legislación Extranjera, n. ${ }^{\text {s }}$ 96-97 (1989). Son especialmente interesantes las anotaciones realizadas por M. DARANAS a las modificaciones introducidas por ambas revisiones

54 Para un comentario sobre esta revisión constitucional, vid. A. NADAIS, A. VItorino y V. CANAS: Constituiçao da República Portuguesa. Texto e Comentários à Lei n. ${ }^{\circ}$ 1/82, Ed. AAFDL, Lisboa, 1983. Así mismo, I. MoraIS, J. M. FerReIRA y R. LeITE PINто: Constituçao da República Portuguesa Anotada e Comentada, Ed. Rei dos Livros, Lisboa, 1983.

55 Sobre esta revisión, vid. J. L. Pereira, J. M. MeIrim, M. Torres y M. Lobo ANTUNES: Constituiçao da República Portuguesa. 2. ${ }^{a}$ Revisao Constitucional, Lisboa, 1989. Así mismo, VITAL MoREIRA: "A segunda revisao constitucional», Revista de Direito Público, IV, n. ${ }^{\circ} 7,1990$, pp. 21 y ss. 
tificación en el plano económico-social (ya iniciada en 1982), en particular por lo que se refiere a la eliminación del radicalismo socializante que impregnaba en el texto originario de 1976 la regulación constitucional de esta materia. La rectificación ideológica, plasmada sobre todo en las modificaciones introducidas en las disposiciones preliminares relativas a los Principios fundamentales, es común a ambas revisiones.

\section{La rectificación ideológica. Los Principios fundamentales}

Si bien toda la Constitución, en su versión originaria de 1976, está cargada de formulaciones de carácter netamente ideológico, es en las disposiciones preliminares relativas a los Principios fundamentales (arts. 1-11) donde tienen una formulación más nítida. Ello explica que haya sido objeto prioritario de la acción del legislador constitucional de 1982 y de 1989, encargado de eliminar las referencias ideológicas que reflejaban las posiciones del constituyente de 1976. Todas las disposiciones preliminares relativas a los Principios fundamentales (excepto el art. 4, relativo a la ciudadanía) se verán afectadas por estas dos primeras revisiones; muy especialmente las que contienen referencias ideológicas, que serán suprimidas o bien sustituidas por otras con enunciados de signo distinto.

1.1. La primera revisión (1982) recalifica al Estado democrático como Estado de derecho democrático ${ }^{56}$, al tiempo que elimina la referencia originaria que vinculaba al Estado democrático con la transición al socialismo (epígrafe art. 2). Asimismo, se sustituye, en el enunciado de la misma disposición constitucional, la alusión a "la creación de las condiciones para el ejercicio democrático del poder por las clases trabajadoras" por la fórmula más neutral de "la realización de la democracia económica, social y cultural»; aunque se mantiene todavía la mención a "la transición al socialismo" (que será eliminada en la siguiente revisión) como objetivo de la República.

Por otra parte, se reformulan las misiones fundamentales del Estado (art. 9), introduciendo una referencia expresa al "respeto de los principios del Estado de derecho democrático" (nuevo al. b), al tiempo que se suprime la mención específica a las clases trabajadoras al referirse a la promoción del bienestar y la calidad de vida del pueblo (nuevo al. d);

56 Sobre el Estado de derecho como principio estructural, vid. J. REIS NovaIS: Os principios constitucionais estruturantes da República portuguesa, Coimbra Ed., 2004, pp. 49 y ss. Así mismo, A. MARTINS: "O Estado de Direito e a ordem política portuguesa", Fronteira, n. ${ }^{\circ}$ 9, 1980, pp. 10 y ss. 
estas modificaciones son compatibles, por el momento, con el mantenimiento de la referencia a "la socialización de los principales medios de producción" (que será también eliminada en la siguiente revisión).

Mayores consecuencias prácticas, sobre todo en el plano institucional, comporta la supresión de la referencia al Movimiento de las Fuerzas Armadas (MFA), al que el constituyente de 1976 hacía "garante de las conquistas democráticas y del proceso revolucionario" y partícipe «en alianza con el pueblo, en el ejercicio de la soberanía» (art. 3.2). En conexión con esta erradicación constitucional del MFA, hay que reseñar la supresión también de la insólita disposición (art. 10) dedicada a constitucionalizar el proceso revolucionario, cuyo desarrollo se confiaba a "la alianza entre el Movimiento de las Fuerzas Armadas y los partidos y organizaciones democráticos ${ }^{57}$. Así mismo, y en relación con el desarrollo del proceso revolucionario, se elimina la previsión constitucional que éste comporta, en el plano económico, de "apropiación colectiva de los principales medios de producción».

La eliminación de las referencias constitucionales al Movimiento de las Fuerzas Armadas (MFA), cuyo protagonismo en el proceso constituyente fue determinante, era obligada desde la perspectiva de la normalización constitucional. Además de las repercusiones en el plano ideológico, contribuyendo a la necesaria desmilitarización de la vida constitucional portuguesa, va a tener también importantes repercusiones en el plano institucional ya que, como se examinará a continuación, comporta la desaparición de instancias institucionales decisivas (como el Consejo de la Revolución) vinculadas al MFA y de difícil encaje en un sistema constitucional normalizado.

En sustitución de las suprimidas alusiones al proceso revolucionario y al MFA, se introduce, en la misma disposición constitucional (art. 10, en su nueva redacción), una referencia expresa al sufragio universal como medio de ejercicio del poder político y a los partidos políticos ${ }^{58}$ como cauce de expresión de la voluntad popular. Estos significativos cambios no eran sino la manifestación del proceso de normalización

57 Sobre las peculiares relaciones entre las FF.AA. y el poder político, vid. D. FREItAS do AmARAL: "La Constitución y las FF.AA.", Revista de Estudios Políticos, n. ${ }^{\circ s} 60-$ 61, op. cit., pp. 607 y ss; también M. G. TELES: «A segunda plataforma de Acordo constitucioal entre MFA e os Partidos Políticos", en AA.VV. (J. MIRANDA, org.): Perspectivas Constitucionales, III, pp. 681 y ss.

58 Vid. M. REBELO DE SOUSA: "La Constitución y los partidos políticos», Revistra de Estudios Políticos, n. ${ }^{\text {s }}$ 60-61, op. cot., pp. 621 y ss. Así mismo, J. TAJADURA: «El estatuto constitucional de los partidos políticos", en La Constitución portuguesa de 1976, op. cit., pp. 145 y ss. 
constitucional que se iniciaba en Portugal con esta primera revisión constitucional.

1.2. La segunda revisión constitucional (1989) completa el proceso de rectificación ideológica iniciado en 1982. No sólo acometerá la revisión de las disposiciones que el legislador constitucional de 1982 no se había atrevido (o no había considerado oportuno) revisar sino que, además, va a re-revisar algunas de las ya revisadas por aquél con el fin de completar y profundizar en la rectificación ideológica. Así, en el art. 1, que no había sido afectado por la revisión de 1982, se elimina la referencia a "la transformación en una sociedad sin clases", sustituida por la fórmula más genérica de "la construcción de una sociedad libre, justa y solidaria». Así mismo, en el art. 2 se elimina por completo la referencia a "la transición al socialismo» ${ }^{59}$ que la anterior revisión de 1982 había respetado parcialmente (la había mantenido en el epígrafe, si bien reformulándola en el enunciado).

La disposición relativa a las misiones fundamentales del Estado (art. 9), que ya había sido objeto de revisión en 1982, vuelve a serlo ahora (1989) reformulando algunos de sus enunciados. Así, la idea de "incentivar la participación democrática de los ciudadanos" sustituye a la de "participación democrática del pueblo" (art. 9.c). Mayor alcance tiene la eliminación de la referencia a "la socialización de los principales medios de producción", que la anterior revisión de 1982 había mantenido, aunque con una formulación distinta, pero que ahora, el legislador constitucional de 1989 suprime por completo. Cabe reseñar también otras modificaciones introducidas en la revisión de 1989 que carecen de relevancia ideológica (así, por ej., la ordenación del territorio o la promoción y difusión internacional de la lengua portuguesa).

Tras las dos primeras revisiones de 1982 y 1989, los principales pronunciamientos ideológicos del constituyente de 1976 -proceso revolucionario, sociedad sin clases, transición al socialismo, socialización de los medios de producción, MFA...- han sido eliminados del texto constitucional, realizándose, en lo esencial, el proceso de rectificación ideológica del texto originario de 1976. Rectificación que también va a tener lugar en el plano institucional y socioeconómico en los términos que a continuación se exponen.

59 Sobre el pronunciamiento socialista del constituyente, vid. J. J. GoMES CANotilno: Direito Constitucional..., op. cit., en particular el apartado dedicado a "A decisao socialista no texto originario da Constituiçao», p. 335. 


\section{La rectificación de la organización institucional}

Junto a la rectificación ideológica, en los términos indicados en los párrafos precedentes, el legislador constitucional de la década de los ochenta asume como tarea prioritaria la rectificación de la organización institucional; en particular, de las instancias más vinculadas a la coyuntura constituyente de 1975-76. Sin pretender agotar el examen de las reformas institucionales introducidas por las revisiones de 1982 y 1989, que dada la extensión de las mismas resultaría imposible tratar en este trabajo ${ }^{60}$, nos vamos a ceñir al examen de dos de ellas, cuya incidencia será determinante en la estructura institucional del sistema: la eliminación del Consejo de la Revolución y la creación del Tribunal Constitucional.

La supresión del Consejo de la Revolución en la estructura institucional de la República no es sino la consecuencia lógica de la supresión de las referencias constitucionales al Movimiento de las Fuerzas Armadas (MFA), del que constituía su proyección orgánica e institucional ${ }^{61}$. Conviene recordar que el Consejo de la Revolución estaba constitucionalizado como órgano de soberanía, al mismo nivel que el Presidente de la República, la Asamblea de la República, el Gobierno y los Tribunales (art. 113.1). Y su configuración constitucional, tanto por su composición, de carácter netamente militar (art. 143) como por las funciones que se le atribuían —nada menos que la de "garante del funcionamiento regular de las instituciones democráticas y de la observancia de la Constitución" (art. 142), entre otras- no tenía encaje alguno en un marco constitucional normalizado.

La desaparición del Consejo de la Revolución se produce de forma simultánea (en la primera revisión de 1982) a la aparición de nuevos órganos constitucionales que, sin ser sustitutivos de aquél —el Consejo de la Revolución, debido a su singularidad (a)constitucional, no es susceptible de sustitución en términos constitucionales- sí tienen relación con algunas de las funciones que realizaba. En este sentido, cabe mencionar el Consejo de Estado, al que el legislador constitucional de 1982 configura como «órgano político consultivo del Presidente de la Repú-

60 Baste reseñar que la revisión constitucional de 1982 afecta a 237 disposiciones constitucionales; y la de 1989 a otras 201.

61 Vid. D. Freitas do Amaral (en ese momento Ministro de Defensa): "La Constitución y las Fuerzas Armadas", op. cit. Así mismo, J. MedeIRos: Portugal en transición, op. cit., en particular el apartado sobre "la revisión constitucional de 1982 y las modificaciones en las relaciones entre el poder político y la institución militar", pp. 281 y ss. 
blica" (art. 144) —el Consejo de la Revolución también tenía funciones consultivas aunque tenía otras, las principales, que sobrepasaban este ámbito-. Es preciso subrayar que el carácter consultivo de este órgano está referido únicamente al Presidente de la República (y no al Gobierno ni a la Administración) y se ciñe a cuestiones estrictamente políticas: disolución de la Asamblea, case del Gobierno, declaración de guerra y firma de la paz...; lo que le diferencia, en su configuración constitucional, de otros órganos con el mismo nombre en otros países (entre ellos, el nuestro) ${ }^{62}$. Así mismo, su composición es netamente política (a diferencia de la militar del Consejo de la Revolución), estando integrado, además de por el Jefe del Estado, que le preside, por los titulares de las principales instituciones políticas de la República (Presidente de la Asamblea, Primer Ministro, Presidente del T.C., Defensor del Pueblo y Presidentes de los Gobiernos regionales).

Otra de las instancias surgidas de la revisión constitucional de 1982, que también tiene relación con la desaparición del Consejo de la Revolución, es el Consejo Supremo de la Defensa Nacional (art. 274). A pesar de su acotamiento al ámbito estrictamente castrense, su proyección constitucional no puede ser obviada, dado el peso determinante que las instancias militares han tenido en el proceso político y constitucional portugués $y$, así mismo, el proceso de desmilitarización constitucional en el que hay que situar la obra del legislador constitucional de $1982^{63}$. El Consejo Supremo de la Defensa Nacional, presidido por el propio Presidente de la República, se configura como un «órgano específico de consulta para los asuntos de la defensa nacional y de la organización, funcionamiento y disciplina de las FF.AA." (art. 274.2), funciones que también quedaban absorbidas anteriormente por el extinto Consejo de la Revolución. Se consigue así deslindar el ámbito de lo militar del político, cuya confusión a través del Consejo de la Revolución era uno de los principales problemas que planteaba el texto aprobado por el constituyente de 1976.

La desaparición del Consejo de la Revolución provoca, además, una serie de efectos inducidos en las relaciones interinstitucionales, en

62 Como observa M. DARANAs, op. cit., el Consejo de Estado suele configurarse, en la experiencia constitucional comparada europea, como el órgano consultivo del Gobierno y de la Administración, en general (así, por ej., entre otras, la Constitución española, art. 107), a diferencia de Portugal, donde se configura como órgano político consultivo del Presidente de la República (art. 144).

63 Sobre la revisión constitucional de 1982 y las FF. AA., vid. D. FreitAS do AmARAL (en ese momento Ministro de Defensa): "La Constitución y las Fuerzas Armadas", op. cit. 
particular entre la Presidencia de la República, el Gobierno y la Asamblea de la República, antes mediatizados por aquél ${ }^{64}$. Hay que recordar, a este respecto, que el constituyente de 1976 atribuía directamente al Consejo de la Revolución la función de "garante del funcionamiento regular de las instituciones democráticas" (art. 145). En líneas generales, puede afirmarse que tras la desaparición de este órgano, la actuación del Presidente de la República va a dejar de verse condicionada permanentemente por el C.R.; así, por ej., en la disolución de la Asamblea o en el nombramiento del Primer Ministro. Lo mismo cabe decir de éste, por lo que se refiere a su sustitución o a la elaboración y aprobación por el Gobierno de los Acuerdos y Tratados internacionales y de los decretos-leyes (arts. 190, 200 y 201), actividades todas ellas interferidas, hasta la revisión de 1982, por el Consejo de la Revolución. Finalmente, la Asamblea de la República también recupera la plenitud de su potestad legislativa, hasta entonces limitada por el Consejo de la Revolución, al que la Constitución reservaba expresamente un ámbito legislativo propio (art. 164.d).

2.2. Junto a la eliminación del Consejo de la Revolución (y los efectos institucionales que ello comporta), la medida más importante adoptada por el legislador constitucional de 1982 (continuada después por el de 1989) es la creación del Tribunal Constitucional ${ }^{65}$. La ausencia de este órgano clave en la estructura institucional del Estado constitucional, cuyas funciones quedaban absorbidas de forma confusa por el Consejo de la Revolución, era, sin duda, una de las lagunas más importantes (posiblemente la más importante en el plano institucional) en la obra del constituyente de 1976. Tanto el legislador constitucional de 1982 como el de 1989 se ocupan de cubrir este importante déficit constitucional del texto originario de 1976.

En sustitución de la Comisión Constitucional y del Consejo de la Revolución, que compartían bajo el predominio de este último aunque de forma confusa el control de constitucionalidad, el Tribunal Constitucional instituido por la primera revisión de 1982 va a asumir plenamente

64 Vid. J. J. Gomes Canotilho y Vital Moreira: Constituçao da República Portuguesa Anotada, II, Coimbra Ed., 1985, en particular el apartado sobre "Articulaçao do sistema de governo" tras la revisión de 1982, pp. 31 y ss. Así mismo, V. PIERGIGLI: "La forma de governo portoghese nella Costituzione e nell'esperienza delle II Repubblica", en AA.VV: Presidenzialismi, Semipresidenzialismi, Parlamentarismi: modelli comparati..., Giappichelli Ed., Torino, 1997, pp. 321 y ss.

65 Vid. J. M. CARDOSO DA COSTA: «O Tribunal Constitucioal Portugués. Sua origem histórica", en AA.VV. (B. COELHO, org.): Portugal. O sistema político e constitucional (1974-1987), Lisboa, 1989, pp. 013 y ss. 
esta función. Inicialmente (1982) el legislador constitucional se ciñe a instituir el T. C., limitándose a determinar su composición -trece miembros: diez designados por la Asamblea de la República y tres cooptados por éstos, precisando además que seis miembros (la mitad menos uno) deberán pertenecer a la judicatura- y a trasvasarle las funciones que en materia de control de constitucionalidad realizaban hasta ese momento (primera revisión de 1982) los extintos Consejo de la Revolución y Comisión Constitucional66.

En una segunda fase (segunda revisión constitucional de 1989) se perfila con mayor precisión la configuración del Tribunal Constitucional, reubicándole en un nuevo Título dedicado específicamente a él (Tit. VI de la Tercera Parte; ubicación que se mantiene hasta la actualidad, como así mismo también la estructura de las disposiciones que le integran, a pesar de los numerosos cambios experimentados por la Constitución). Se le define como la instancia a la que "compete específicamente administrar justicia en materias de naturaleza jurídico-constitucional» (art. 223), se mantiene la composición ya establecida en la anterior revisión y se le atribuyen, además del control de constitucionalidad, otras funciones de carácter político-institucional en relación con la sustitución presidencial (incapacidad, pérdida del cargo, condiciones de los candidatos al cargo), en materia electoral (regularidad del procedimiento electoral), referendaria (constitucionalidad y legalidad) y, por último, verificación de la legalidad de los partidos políticos y coaliciones, pudiendo ordenar, en su caso, la extinción de acuerdo con la Constitución y la ley (art. 225) ${ }^{67}$.

Por lo que se refiere al control de constitucionalidad en particular, el Tribunal Constitucional pasa a asumir en toda su plenitud esta función; aunque ello sea lógico, es preciso hacer una mención específica al respecto ya que esta función, en el texto originario de 1976, era asumida por el Consejo de la Revolución (y auxiliarmente por el Consejo Constitucional). Las revisiones de 1982 y 1989 reformulan con mayor precisión y mejor sistemática las distintas modalidades de control de constitucionalidad distinguiendo, mediante extensas disposiciones diferenciadas, el control concreto de constitucionalidad en aplicación de la ley por los Tribunales (art. 280) y el control abstracto de constitucionalidad ante cualquier norma que vulnere la Constitución (art. 281).

66 Vid. A. Ribeiro Mendes: "O Conselho da Revoluçao e a Comissao Constitucional na fiscalizaçao da constitucionalidade das leis», en AA.VV. (B. CoELHo, org.): Portugal. O Sistema político e constitucional, op. cit., pp. 925 y ss.

67 Para un desarrollo más amplio de la evolución del sistema de justicia constitucional portugués, vid. G. VAGLI: L'evoluzione del sistema di giustizia costituzionale in Portogallo, Pisa, 2001. 
Además de estas dos modalidades, clásicas y comunes, de control de constitucionalidad, se acogen también otras dos modalidades (ya contempladas en el texto originario) que singularizan, una vez más, el peculiar modelo de control de constitucionalidad portugués. Así, se constitucionaliza expresamente (lo que no es común en otros ordenamientos) el control preventivo de constitucionalidad ${ }^{68}$, autorizando para ello, en los supuestos que se especifican pormenorizadamente - Tratados y Acuerdos internacionales, leyes orgánicas, leyes, decretos-leyesal Presidente de la República, al Jefe de Gobierno, a los Ministros y a 1/5 de los diputados (art. 278). Así mismo, se contempla también ( y ello es menos común aun) la figura de la inconstitucionalidad por omisión ${ }^{69}$ cuando se aprecie, bien por el Presidente de la República, el Defensor del Pueblo o los Presidentes de las Asambleas legislativas regionales (estos últimos en su propio ámbito competencial) "el incumplimiento de la Constitución por omisión de las medidas legislativas necesarias para hacer efectivas las normas constitucionales" (art. 283).

La creación del Tribunal Constitucional (simultánea con la eliminación del Consejo de la Revolución; y también de la Comisión Constitucional) y su configuración progresiva a través de las revisiones constitucionales de 1982 y 1989 con los rasgos que presenta en la actualidad, supone un paso decisivo en el proceso de normalización institucional emprendido con estas revisiones ${ }^{70}$. El legislador constitucional de 1982 y 1989 va a dotar así a la República portuguesa de un órgano clave, del que carecía hasta entonces, en la estructura institucional del Estado constitucional, al tiempo que suprimía otros que tienen difícil encaje en éste, contribuyendo con ello a la homologación constitucional de Portugal.

68 Como observa M. DARANAS, op. cit., se trata de un mecanismo de control de constitucionalidad poco usual; el referente más típico en Europa es el francés de la V República (art. 61), en el que probablemente se inspira el constituyente portugués de 1976, aunque en este caso el control previo de constitucionalidad lo ejercía originariamente el Consejo de la Revolución.

69 Es otra de las novedades, sin apenas correspondencia en el constitucionalismo comparado, introducidas por el constituyente de 1976 y que, en este caso, se mantiene en la actualidad. Sobre este tema, vid. J. FERNÁNDEZ RoDRíGUEZ: "La figura de la inconstitucionalidad por omisión portuguesa ante el siglo XXI", en La Constitución portuguesa de 1976, op. cit., pp. 229 y ss. Así mismo, J. TAJADURA: "La inconstitucionalidad por omisión y los derechos sociales", en AA.VV. (J. CORCUERA coord.): La protección de los derechos fundamentales en la UE, Dykinson, Madrid, 2002 , pp. 247 y ss.

70 Ley $n .^{\circ}$ 28/82, de 15 de Noviembre, por la que se crea el Tribunal Constitucional (posteriormente modificada por la ley n. ${ }^{\circ}$ 13-A/98). Para un comentario sobre esta ley, vid. A. NovaIS, A. VITORINO y V. CANAS: Lei sobre a organizaçao, o funcionamento e o processo do Tribunal Constitucional, Lisboa, 1984. 


\section{La rectificación de la Constitución económica}

La Constitución económica es el pasaje constitucional (Segunda Parte, arts. 80-110) que experimenta mayores cambios. Recuérdese (cfr. supra) las muy especiales características que presentaba el texto originario de 1976, impregnado de un fuerte radicalismo socializante ajeno por completo al tratamiento que esta materia recibe en los textos constitucionales de los países de Europa occidental ${ }^{71}$. Debido a ello, la necesidad de homologación constitucional de Portugal con los países de su mismo espacio geográfico y político, tarea que asume el legislador constitucional en las dos primeras revisiones de 1982 y 1989, va a exigir, más que en ninguna otra materia, una profunda revisión constitucional.

Si bien la rectificación constitucional en el plano económico se inicia desde la primera revisión (1982), en la que no sólo se introducen importantes cambios sino que, sobre todo, se marca una nueva orientación divergente con la del texto originario, será con la segunda revisión de 1989 cuando el proceso de rectificación de la Constitución económica se manifieste con toda claridad ${ }^{72}$. Es a partir de este momento (1989) cuando puede afirmarse que el modelo constitucional económico portugués se homologa con el de sus vecinos euroccidentales. Este proceso de homologación constitucional tendrá continuidad en las siguientes revisiones, ya en el marco del proceso de integración europea: la tercera revisión (1992) es para constitucionalizar el Tratado de la Unión Europea de Maastricht y las posteriores siguen la misma ruta, dentro ya del marco de la Unión Europea. La Constitución económica resultante de este intenso y continuado proceso de rectificación poco tendrá en común con el texto originario de 1976.

Los principios que inicialmente (1976) constituían el fundamento de la organización económico-social - «desarrollo de las relaciones de producción socialistas... apropiación colectiva de los principales medios de producción... ejercicio del poder democrático por las clases trabajadoras" (art. 80 en su redacción inicial)— irán desapareciendo todos en

71 Sobre la Constitución económica portuguesa, en general, vid. G. D'OLIVEIRA MARTINS: "La Constitución económica portuguesa: del programa a la mediación», $R e-$ vista de Estudios Políticos, op. cit., pp. 741 y ss. Sobre el mismo tema, vid., así mismo, mi trabajo "La revisión de la Constitución económica», en La Constitución portuguesa de 1976, op. cit., pp. 93 y ss.

72 Por lo que se refiere a la primera revisión (1982), vid. A. DE SouSA: «A Revisao da Constituçao Económica», Revista da Ordem dos Abogados, 1982, pp. 601 y ss..

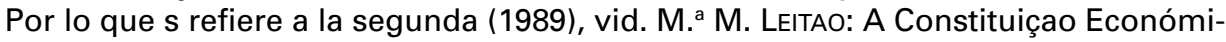
ca depois da segunda revisao constitucional", Revista de Direito Público, 1991, pp. 9 y ss. 
el curso de las sucesivas revisiones constitucionales. En su lugar, se introducen formulaciones nuevas que revelan una orientación divergente; tal es el caso de la forma de concebir la coexistencia del sector público, cooperativo y privado, que tras la primera revisión de 1982 se erige en el principio básico del orden económico; si bien de forma muy diferente a como se contemplaba la coexistencia de los sectores económicos en el texto originario (que también hacía referencia a ella, aunque con un claro predominio del sector público, progresivamente relegado a medida que avanza el proceso de revisión constitucional) ${ }^{73}$. La revisión de 1989 hace una referencia específica a la protección del sector cooperativo y social (diferenciado del sector público). Posteriormente, la cuarta revisión, de 1997, constitucionalizará explícitamente "la libertad de iniciativa y de organización empresarial en el ámbito de una economía mixta» (nuevo al. c) del art. 80, tras la revisión de 1997).

En esta misma orientación hay que situar los cambios introducidos en las tareas prioritarias del Estado (art. 81) en el ámbito económico y social. En este sentido, la revisión de 1982 elimina la referencia a «la transformación de las estructuras económico-sociales" que figuraba en el texto originario, así como toda alusión al "desarrollo de las relaciones socialistas de producción". La revisión de 1989, por su parte, avanza en la misma dirección eliminando, en esta ocasión, las referencias a las nacionalizaciones como medio para hacer frente a los monopolios privados (que la primera revisión de 1982 había mantenido); y también a la reforma agraria, cuestión ésta que en Portugal, dada la estructura de su población, tiene una especial incidencia social. Más tarde, la cuarta revisión de 1997, además de correcciones de carácter actualizador (así, por ej. la referencia al desarrollo sostenible), constitucionaliza de forma expresa, como tarea prioritaria del Estado "asegurar el funcionamiento eficaz de los mercados", lo que más allá de su funcionalidad real -el Estado no necesita autorización constitucional explícita para intervenir en este terreno- es indicativo de las nuevas prioridades, muy alejadas de las del constituyente de 1976, del legislador constitucional dos décadas después (1997).

Las nacionalizaciones de los medios de producción, que constituían uno de los ejes centrales de la Constitución económica en su versión originaria de 1976, van a ser también objeto de la acción revisora del legislador constitucional. Acogidas inicialmente por el constituyente de

73 Sobre la problemática suscitada por las distintas interpretaciones en torno a la Constitución económica, vid. J. MIRANDA: "A interpretaçao da Constituiçao Económica", en Estudos em homenagem ao Professor Doctor Alfonso Rodrigues Queiró (separata), Coimbra, 1987. 
1976 como "conquistas irreversibles de las clases trabajadoras" en una disposición dedicada específicamente a ellas bajo el epígrafe: "Nacionalizaciones efectuadas después del 25 de Abril de 1974" (art. 83), van a experimentar un cambio radical tras la revisión de 1989, que preverá justamente todo lo contrario; es decir, la posibilidad de reprivatización de las nacionalizaciones efectuadas al calor de la revolución de los claveles ${ }^{74}$. Así mismo, se elimina la previsión inicial de expropiación mediante ley de los grandes latifundistas sin indemnización alguna (art. 82.2 en su redacción originaria), sustituida por la previsión de reserva de ley sobre "las formas de intervención y de apropiación pública de los medios de producción, así como los criterios de fijación de la correspondiente indemnización" (art. 93 tras la revisión).

La iniciativa privada, que era reconocida expresamente en el texto originario como uno de los principios del sistema económico, si bien «en el marco definido por la Constitución, por la ley y por el Plan... como instrumento de progreso colectivo" (art. 85), va a experimentar importantes cambios en su regulación constitucional; como no podía ser de otra forma teniendo en cuenta la orientación rectificadora que guiaba al legislador de revisión constitucional. Resulta ilustrativa al respecto la nueva terminología empleada - por ej., empresa privada sustituye a la expresión inicial más genérica «iniciativa privada»- así como la supresión de las referencias al Plan y al progreso colectivo que enmarcaban en el texto originario la iniciativa económica privada. Se altera también sustancialmente la regulación de la posible intervención del Estado en la gestión de la empresa privada, contemplada en el texto originario de 1976 con carácter general — «para conseguir el interés general y los derechos de los trabajadores»-, con carácter transitorio tras la primera revisión de 1982 — «el Estado sólo podrá intervenir en la gestión de las empresas privadas de forma transitoria»- para finalmente, tras la revisión de 1989, ver limitada la intervención a "los casos expresamente previstos por la ley y, en principio, previa decisión judicial».

El tratamiento de la planificación económica, tema al que la Constitución portuguesa dedica íntegramente un Título específico, lo que no es nada usual en nuestro modelo constitucional ${ }^{75}$, va a experimentar

74 Vid. A. DE Sousa FRANCO: «Da irreversibilidade reversível das nacionalizaçoes à reversibilidade irreversible das nacionalizaçoes", en AA.VV.: Os 20 anos da Constituiçao de 1976, op. cit., pp. 167 y ss.

75 Cfr. en Constituciones Europeas (M. DARANAS), op. cit., el tratamiento dispar que esta materia tiene en la Constitución portuguesa en relación con los textos constitucionales euroccidentales $y$, al mismo tiempo, la afinidad con el tratamiento del constitucionalismo de los países del Este en esa época (mediados de los años setenta). 
también importantes modificaciones. Ello era lógico a la vista del cambio radical de tendencia en la orientación económica que se impone a partir del inicio de la década de los ochenta, con el auge de las corrientes de signo neoliberal, opuestas por completo a los planteamientos planificadores del constituyente de 1976 y que tendrán su reflejo en el legislador constitucional de 1982 y 1989. De acuerdo con esta nueva orientación, se eliminan (revisión de 1982) las referencias del texto originario al Plan, concebido en función de "la construcción de una economía socialista, a través de la transformación de las relaciones de producción y acumulación capitalistas" (art. 91.1 en el texto originario de 1976). La segunda revisión (1989) suprime no sólo la referida concepción del Plan sino la misma referencia al Plan (en singular y entendido como el marco global y unitario de la actividad económica), sustituida por la referencia a los planes (en plural) de desarrollo económico y social para promover el crecimiento económico. Se puntualiza, asimismo, el carácter indicativo de la planificación para los sectores público no estatal, privado y cooperativo (revisión de 1982), eliminando finalmente toda alusión al carácter imperativo del plan, incluso para el sector público estatal (revisión de 1989).

En relación con el tema que nos ocupa, es preciso hacer una mención sobre el órgano encargado de la elaboración y ejecución del Plan (los planes, a partir de 1989), al que la Constitución dedica una disposición específica. Inicialmente, hasta la segunda revisión de 1989, todo lo relativo al Plan se confiaba al Consejo Nacional del Plan, órgano cuyas funciones se ceñían a la coordinación de la elaboración del Plan, asegurando "la participación de la población a través de los entes autónomos, comunidades locales, organismos de las clases trabajadoras y entidades representativas de actividades económicas" (art. 94.2). Este órgano será sustituido, tras la segunda revisión de 1989, por el Consejo Económico y Social, al que la propia Constitución define como "órgano de consulta y concertación en el campo de la política económica y social» (art. 75); junto a esta función, también se le asigna la de "participar en la elaboración de los planes de desarrollo económico y social» así como las demás que le asigne la ley ${ }^{76}$.

La reforma agraria, cuyo tratamiento constitucional en el texto originario de 1976 difería por completo del que este tema tiene en el

76 La ley que regula este órgano - lei n. ${ }^{\circ}$ 108/91, de 17 de Agosto; y el Decretolei n. ${ }^{\text {s }} 90 / 92$, de 21 de Mayo- lo hace de forma parecida a como en otros países se regulan órganos similares; entre ellos, nuestro Consejo Económico y Social, que también se crea por las mismas fechas (ley 21/1991 (BOE de 18 Junio). 
constitucionalismo euroccidental ${ }^{77}$, va a experimentar también profundas modificaciones, hasta el punto de resultar irreconocible, tras las revisiones efectuadas, en relación con el texto aprobado por el constituyente de 1976. Incluso la propia denominación - reforma agrariaque encabezaba el originario Título IV desaparecerá para ser sustituida, tras la segunda revisión de 1989, por la de política agraria, englobada conjuntamente con la política comercial e industrial (Tit. III, después de la revisión de 1989).

Todas las disposiciones que integraban este pasaje constitucional se van a ver afectadas por la acción revisora del legislador constitucional. La primera revisión (1982) suprime las referencias a la sociedad socialista así como a "las nuevas relaciones de producción en la agricultura" que el texto originario vinculaba a la reforma agraria, sustituyéndolas por alusiones genéricas a la política agraria. La siguiente revisión (1989) elimina toda referencia a la noción misma de reforma agraria, reemplazándola por la de "política de reordenación y reconversión agrarias." Esta misma revisión suprime la previsión constitucional originaria de expropiación de "los latifundios y las grandes expropiaciones capitalistas", sustituida por la de "redimensionamiento de las unidades de explotación agrícolas que tengan una dimensión excesiva» (1989) ${ }^{78}$.

Aunque los cambios en el ámbito específico de la Constitución financiera (Tit. V: Sistema financiero y fiscal) son de menor entidad que los efectuados en los ámbitos reseñados en los párrafos precedentes — principios rectores de la organización económica, planificación económica, reforma agraria - también en ese terreno se va a hacer sentir la orientación rectificadora impulsada por el legislador de revisión constitucional $^{79}$. Cabe mencionar en este sentido la supresión, en la primera revisión de 1982, de los objetivos socializadores — «socialización progresiva y efectiva de la economía» (art. 105.1)— que el constituyente

77 Puede verse también en M. DARANAS: Las Constituciones Europeas, op. cit., la disparidad en el tratamiento de esta materia en los textos constitucionales euroccidentales y el portugués. Sobre la reforma agraria en el periodo constituyente, vid. A. BARRETO: "Reforma Agraria y revolución en Portugal (1974-76)», Revista de Estudios Políticos, n. ${ }^{\text {os }} 60-61$, op. cit., pp. 413 y ss.

78 Para un tratamiento más amplio sobre la evolución del proceso de reforma agraria, vid. BERNARD ROuX: "Reforme et contre-reforme agraire en Portugal», Revue Tires Monde, XXIII, n. ${ }^{\circ} 89$ (1982); también "Reforme et contre-reforme agraire», en Portugal. Vingt ans après la Revolution del oeillets, La Documentation Française, Paris, 1994, pp. 231 y ss.

79 Vid. G. D'Oliveira Martins: «Revisao constitucional. Economia e Finanças», Estado \& Direito, n. ${ }^{\circ} 3,1990$. 
de 1976 asignaba al sistema financiero, reemplazados tras la segunda revisión (1989) por una alusión de carácter genérico al "desarrollo económico y social», nuevo enunciado que se ha mantenido hasta la actualidad.

El Banco de Portugal, objeto de constitucionalización directa (art. 105.2), apenas experimenta modificación en las dos primeras revisiones (1982 y 1989). Será en las dos siguientes (1992 y 1997) cuando va a experimentar una profunda reconfiguración constitucional, al igual que los demás Bancos Centrales de los países de la U.E., para adecuarse al nuevo marco del sistema bancario - SEBC y BCE- instaurado por los Tratados de la Unión Europea en Maastricht (1992) y Ámsterdam (1997). Finalmente, por lo que se refiere al sistema fiscal, en el que algunas de sus principales figuras impositivas son objeto de una mención constitucional explícita (lo que es inusual en el constitucionalismo comparado), se eliminan las referencias socializadoras originarias ${ }^{80}$; así, por ej., la previsión, ciertamente voluntarista, de utilizar el IRPF para «limitar las rentas a un máximo nacional definido anualmente por ley" (art. 107.1 en su redacción originaria); o, en relación con la imposición sobre el consumo (art. 107.4), la eliminación de la referencia del texto originario a su vinculación con "las necesidades de socialización de la economía, eximiendo de aquélla [imposición sobre el consumo] a los bienes necesarios para la existencia de los más débiles económicamente y sus familias" (art. 107.4 en su redacción originaria).

Como ya se ha señalado anteriormente, la Constitución económica es el pasaje que experimenta cambios más profundos en las dos primeras revisiones. Puede afirmarse que después de 1989 (segunda revisión), ninguno de los elementos más característicos del originario modelo económico constitucional portugués se mantiene; no sólo los de connotaciones más retóricas sobre el «desarrollo de las relaciones socialistas de producción... la apropiación colectiva de los principales medios de producción", sino también los que hacen referencia a cuestiones más vinculadas a las políticas a desarrollar: planificación económica, reforma agraria, nacionalizaciones, tareas prioritarias del Estado ${ }^{81}$. En su

80 Vid. M. PIRES: "A Constituiçao de 1976 e a fiscalidade», en Estudos sobre a Constituiçao, II, p. 417 y ss.. Así mismo, J. J. TEIXEIRA RIBEIRO: "O sistema fiscal na Constituçao revista", Boletim de Ciencias Económicas, vol. XXV, pp. 219 y ss.

81 Es muy expresiva la pregunta que se formula E. PAZ FERREIRA y que proporciona el título a uno de sus estudios sobre el tema: "A Constituiçao Económica de 1976: Que reste-t-il de nous amours?", en Perspectivas Constitucionais, l, op. cit., pp. 383 y ss. Así mismo, VitAl Moreira: "Revisao e revisoes: A Constituiçao ainda é a mesma?», en Os 20 anos da Constituiçao de 1976, op. cit., p. 197. 
lugar se introducen nuevas formulaciones, de signo distinto, y divergente con las originarias, que marcan la nueva orientación a seguir a partir de ese momento.

\section{LA REMODELACIÓN CONSTITUCIONAL. LAS REVISIONES DE 1997 Y 2004}

Una vez realizada la profunda rectificación constitucional de la década de los ochenta (revisiones de 1982 y 1989), el legislador constitucional portugués va a proseguir su obra revisora acometiendo, a continuación, tareas que podríamos caracterizar como de remodelación del ya rectificado sistema constitucional portugués. A esta finalidad responden las revisiones constitucionales de 1997 y 2004 (cuarta y sexta por orden cronológico), a través de las cuales se aborda la reordenación progresiva del sistema constitucional, sobre la base del acusado giro rectificador ya efectuado por las dos primeras revisiones. En el conjunto del dilatado y continuado proceso de revisión constitucional portugués puede decirse que este tipo de revisiones, de carácter remodelador y reordenador, son las que mejor responden a los fines típicos de la reforma constitucional ordinaria.

A diferencia de las dos primeras revisiones de 1982 y 1989, las de 1997 y 2004 (que examinaremos a continuación) carecen del carácter acusadamente rectificador que presentaban aquéllas; aunque ello no impide que también tengan, en ambos casos, carácter global y general (sobre todo la primera de ellas (1997) ${ }^{82}$. Esta característica común es la que las distingue de las otras tres revisiones (1992, 2001 y 2005, de las que nos ocuparemos más adelante), circunscritas a cuestiones limitadas y puntuales relativas a la inserción de Portugal en el cambiante marco internacional, en particular en la Unión Europea. En líneas generales pueden ser caracterizadas como el prototipo de las reformas ordinarias (a diferencia de las grandes revisiones de rectificación constitucional de 1982 y 1989) de carácter general (a diferencia de las limitadas y puntuales de 1992, 2001 y 2005), que suponen una importante contribución a la normalización de la vida constitucional portuguesa.

82 Lei Constitucional 1/1997 (Diário da República, I Serie A, n. ${ }^{\circ} 218$, de $2 .^{\circ}$ de Septiembre de 1997). Un comentario, de carácter general, sobre esta revisión constitucional puede verse en A. ArAujo: A revisao constitucional de 1997, Lisboa, 1999; A. Sousa Pinheiro y M. Joao Fernandes: Comentário à IV Revisao Constitucional, Lisboa, 1999. 
1. La revisión constitucional de 1997. Características generales y principales correcciones tendentes a la remodelación del sistema constitucional

En el marco general del continuado proceso de revisión portugués, la revisión de 1997 tiene la característica (común a las dos primeras de 1982 y 1989) de su llamativa e inusual extensión. Casi las dos terceras partes de las disposiciones constitucionales resultan afectadas, en diversa medida, por la revisión de 199783; a ello hay que añadir también la renumeración de casi la mitad de las disposiciones constitucionales (dato que es preciso tener siempre muy en cuenta en el estudio de los textos constitucionales portugueses tras las sucesivas revisiones). Todo ello da cuenta de la amplitud, en términos cuantitativos, de la revisión efectuada por el legislador constitucional en 1997 que, como ya se ha reseñado, tiene carácter general y afecta a todos los pasajes integrantes del texto constitucional de 1976 (tras las profundas rectificaciones de 1982 y 1989, y la modificación puntual, referida a la UE, de 1992).

En esta ocasión, la extensa revisión constitucional de 1997 va a ser precedida por un Acuerdo político global entre las dos principales fuerzas políticas portuguesas —Partido Social Demócrata y Partido Socialista- ${ }^{84}$ en el que se precisan previamente los términos de la revisión constitucional. Este proceder por parte de los dos partidos mayoritarios va a suscitar una fuerte reacción crítica, no sólo en las fuerzas políticas excluidas (todas las demás) sino también en círculos doctrinales que llegan a calificar el referido Acordo de Revisao PSD-PS como una "manifiesta injusticia procesal». Se argumentaba, en este sentido, que no resulta admisible hurtar el debate al órgano previsto para ello - la Comisión Especial para la Revisión Constitucional (CERC) - porque los problemas fundamentales de la vida política, de forma muy especial los que atañen a la Constitución, no pueden tratarse secretamente entre dos fuerzas políticas, por mayoritarias que sean, sino que deben ser objeto de debate, desde el primer momento, en términos plurales, abiertos y contradictorios; y porque, en definitiva, el método empleado supone un claro déficit en la política democrática deliberativa que debe inspirar a la República ${ }^{85}$.

83 La referida ley constitucional 1/97 (4. ${ }^{\circ}$ revisión constitucional) consta de 198 arts. que modifican aproximadamente otras tantas disposiciones constitucionales, sobre un total de 299 con que contaba el texto constitucional en su conjunto; se modifica, por tanto, alrededor de dos tercios del total, además de renumerar buena parte de las disposiciones modificadas.

84 P. OTERO: O Acordo de revisao constitucional: significado político e jurídico, Lisboa, 1997.

85 J. J. Gomes Canotilno: Direito Constitucional..., op. cit., p. 213. 
La revisión constitucional de 1997 carece de un núcleo central en torno al cual se articula el conjunto de la revisión (o, al menos, los elementos más importantes de la misma); así, la rectificación ideológica e institucional en la de 1982; o en el plano económico, en la de 1989; o relativa a la UE, en la de 1992. El carácter más disperso del objeto de la revisión constitucional en 1997 (como, así mismo, en la de 2004, tal y como se verá en su momento) impide que podamos contar con un eje directriz tan definido como teníamos en las revisiones anteriores. Hay que adelantar, no obstante, que el grueso de las disposiciones revisadas en 1997 se refieren a la organización institucional de la República y en menor medida, aunque también importante, al régimen de derechos y libertades.

A pesar de que hubo propuestas que propugnaban la supresión o, en su caso, la drástica rectificación del Preámbulo constitucional, en nombre de la "limpieza semántica» y por considerar que en él se simboliza el "pecado original» ${ }^{86}$ del constituyente de 1976, sin embargo este pasaje constitucional permaneció inalterado; incluidas las referencias a la transformación revolucionaria de la sociedad portuguesa (par. $2^{\circ}$ ) y a la senda abierta por la Asamblea constituyente "hacia una sociedad socialista" (par. $4 .^{\circ}$ ) que son las únicas de estas características que se conservan del texto originario de 1976 y que se siguen manteniendo en la actualidad.

Por lo que se refiere a los Principios fundamentales contenidos en las disposiciones preliminares (arts. 1-11), una vez realizada la profunda rectificación de las primeras revisiones (1982 y 1989), la revisión de 1997 apenas introduce modificaciones de relieve. Baste reseñar como más destacables la referencia expresa al régimen autonómico insular y al principio de subsidiariedad en las relaciones autonómicas (art. 6). Y en la disposición dedicada a fijar las tareas fundamentales del Estado (art. 9) se introducen referencias específicas a los derechos medioambientales (junto a los ya reconocidos económicos, sociales y culturales) y al "desarrollo armónico de todo el territorio nacional». Así mismo, el principio de igualdad ${ }^{87}$ va a tener concreción en el ámbito específico de las relaciones de género mediante la inclusión de un nuevo alínea (9. h)

86 Son muy expresivas las invocaciones a la «limpieza semántica» por parte del PSD y al "pecado original» por parte del CDS-PP, para suprimir el Preámbulo. Los proyectos de revisión pueden verse en Diário da Assembleia da República, de 8 de Abril de 1996 (Separata n. $6 / \mathrm{VII}$ ).

87 Sobre la igualdad como principio estructural, vid. J. REIS NovAIS: Os principios constitucionais estruturantes..., op. cit., en particular, el pasaje dedicado al principio de igualdad, pp. 101-115. 
que inserta como tarea del Estado la promoción de la igualdad entre hombres y mujeres. Adiciones, todas ellas, que revelan la sensibilidad del legislador constitucional ante las nuevas concepciones que venían abriéndose paso en este periodo en materia medioambiental, de modelo de desarrollo y de equiparación de género.

Por lo que se refiere a la Constitución económica (Parte Segunda, arts. 80-110), que ya había experimentado una profunda rectificación en las dos primeras revisiones (y especialmente en la segunda, 1989), va a ser objeto de diversas modificaciones, en la misma orientación liberalizadora de las revisiones de 1982 y 1989, aunque sin tener el alcance y la entidad de éstas. El legislador constitucional de 1997 se limita a caminar por la senda ya trazada por sus predecesores de 1982 y 1989, aportando nuevos materiales de las mismas características con los que proseguir la obra liberalizadora iniciada en las revisiones precedentes.

Por lo que se refiere a los principios en que se fundamenta la organización económica ${ }^{88}$, cabe reseñar la introducción de una referencia explícita a "la libertad de iniciativa y de organización empresarial en el marco de la economía mixta" (nuevo alínea c/ del art. 80); así mismo, entre las tareas prioritarias del Estado en el ámbito económico, se introduce una referencia expresa a la de "asegurar el funcionamiento eficiente de los mercados" (nueva redacción del al. e/ del art. 81); en la misma línea se incluye como nueva obligación específica del Estado, la de incentivar la actividad empresarial (art. 82.1), al tiempo que se flexibiliza el ámbito de la actividad empresarial privada en los sectores básicos de la economía (art. 86.3) en los términos que "pueda determinar» la ley (anteriormente se preveía que la ley "determinará» los sectores básicos en los que queda prohibida la actividad empresarial privada).

En sintonía con estas modificaciones en los principios de la organización económica (Tit. I de la Parte Segunda) se introducen también diversas modificaciones de la misma orientación en el resto de los Títulos que integran esta Segunda Parte (en la que se agrupan las disposiciones relativas a la Constitución económica): reformulando la regulación constitucional de los planes (inicialmente el Plan, en singular, de carácter integral y global), la política agraria (originariamente la reforma agraria) y el sistema financiero y fiscal ${ }^{89}$.

88 Vid. J. MiRANDA: "Les fondements constitutionnels de l'organisation economique", Revue Européenne de Droit Public/European Review of Public Law (REDP/ERPL), Vol 6, n. ${ }^{\circ}$ 1, 1994.

${ }_{89}$ Un desarrollo más amplio de estos temas puede verse en mi trabajo «La revisión de la Constitución económica», op. cit., pp. 119 y ss. 
En materia de derechos y libertades, la contribución del legislador constitucional de 1997 no debe pasar desapercibida. Si bien las dos primeras grandes revisiones de 1982 y 1989 (la tercera de 1992 es muy breve y se ciñe a la U.E.) ya habían tratado el tema, lo habían hecho de forma tangencial ya que el núcleo central de las mismas se refería a otras cuestiones: rectificación ideológica e institucional en la de 1982 y rectificación en el ámbito económico en la de 1989. La cuarta revisión de 1997, que a diferencia de las tres anteriores carece de una idea fuerza dominante (en palabras de J.J. Gomes Canotilho), aborda este tema con más amplitud, aportando además novedades de interés dignas de merecer nuestra atención.

Un primer bloque de reformas tiene como finalidad la mejora del régimen de derechos y libertades. Entre ellas, cabe reseñar la explicitación constitucional del derecho al desarrollo de la personalidad (art. 26.1); más que por la literalidad de los términos, ya que el desarrollo de la personalidad, sea reconocido expresamente o no, es un fundamento básico de todo Estado de derecho, su explicitación constitucional supone, como observa Barcelar Gouveia ${ }^{90}$, una válvula de seguridad para asegurar mejor la esfera de la personalidad y un apoyo a la tarea de la jurisprudencia para descubrir nuevos y específicos derechos básicos de personalidad. En este mismo bloque de medidas dirigidas a mejorar el régimen de derechos hay que incluir las referentes a la efectividad de la tutela jurisdiccional de los derechos; entre ellos, la asistencia letrada ante cualquier autoridad (art. 20.2) y el derecho a un procedimiento judicial basado en el principio de celeridad que permita una resolución judicial en un plazo razonable (art. 20. 4 y 5).

En segundo lugar, encontramos reformas que comportan una reformulación sustancial del régimen de derechos. Es el caso, en particular, de la extradición, hasta ese momento inaplicable a los ciudadanos portugueses y ahora admisible en el marco de los Convenios internacionales suscritos por Portugal (art. 33.3). Esta «relativización del patrimonio jurídico-constitucional portugués", en palabras de Gomes Canotilho, es reveladora, por otra parte, de la internacionalización y eurocomunitarización del derecho constitucional, especialmente en materia de derechos y libertades ${ }^{91}$, a las que el legislador constitucional portugués va a proporcionar cobertura en su cuarta revisión de 1997.

90 J. Barcelar GouveiA: "The fourth review ot the Portughese Constitution", European Review of Public Law/Revue Européenne de Droit Public (ERPL/RDPR), Vol. 11, n. 1 (1999), p. 206.

91 La regulación de la extradición debe ser encuadrada en el marco del Tratado de Schengen, Convención de Dublín y Tratado de Roma sobre el Tribunal Penal Internacional. 
Junto a las modificaciones reseñadas con la finalidad de mejorar o reformular el régimen de derechos, se pueden hallar también cambios que suponen auténticas innovaciones constitucionales. Así, por ej., en lo que Gomes Canotilho califica como uterreno movedizo de la Constitución bio-médica ${ }^{92}$, en el que el legislador constitucional portugués de 1997 se introduce con el fin de consagrar constitucionalmente el deber del legislador de garantizar "la identidad genética del ser humano, especialmente en la creación, desarrollo y utilización de la tecnología y en la experimentación científica» (art. 26.3); disposición que resulta insólita en el constitucionalismo comparado pero que dada la creciente actualidad del tema va a ser, sin duda, (ya lo es) objeto preferente de atención por los constitucionalistas ${ }^{93}$.

En la misma orientación innovadora hay que situar las modificaciones referentes a la utilización de la informática (art. 35), disposición constitucional pionera ya presente en el texto originario de 1976 y modificada en las dos revisiones precedentes de 1982 y 1989. El legislador constitucional de 1997 vuelve a hacerla objeto de su atención nuevamente, introduciendo, como los anteriores, nuevas previsiones tendentes a reforzar la protección de los ciudadanos en el ámbito de la informática. La atención que merece esta disposición (y sus sucesivas revisiones) tiene especial interés ya que se trata de uno de los terrenos, aun insuficientemente explorados desde el punto de vista constitucional, que previsiblemente va a ser en un futuro próximo objeto de atención por los constitucionalistas ${ }^{94}$.

Por último, los derechos de participación política de la ciudadanía van a experimentar una apreciable ampliación con la revisión de 1997. Cabe reseñar, en este sentido, la extensión del derecho al voto en las elecciones presidenciales a los ciudadanos portugueses residentes en el extranjero, aunque con la condición de que se acredite "la existencia de lazos de efectiva vinculación con la comunidad nacional» (nuevo art. 121.2). Así mismo, estos ciudadanos — residentes en el extranjero- podrán ejercer el derecho al voto en el referéndum nacional sobre materias que les incumban (nuevo art. 115.12). Por otra parte, se amplía la posibilidad de que el referéndum sea convocado (por el Presidente de la República) como resultado de una iniciativa ciudadana dirigida a la

92 J. J. Gomes Canotilho: Direito Constitucional..., op. cit., p. 212.

93 Sobre este tema, vid. P. OTERO: Personalidade e identidade pessoal e genético do ser humano: Um perfil constitucional da bioética, Coimbra, 1999; J. LoUREIRO: $O$ direito à identidade genética do ser humano, Coimbra, 1999.

94 Vid. P. MOTA PINTO: "A protecçao da vida privada e a Constituiçao", Boletim da Faculdade de Direito de Coimbra, LXXVI, 2000, pp. 153 y ss. 
Asamblea de la República (antes sólo a propuesta de la Asamblea de la República o del Gobierno). En cualquier caso, el referéndum sólo tendrá efectividad si la participación en él supera la mitad del censo electoral.

También a nivel local se abre la puerta a la participación directa de los ciudadanos mediante el referéndum local, si bien circunscrito a las materias para las que sean competentes los entes locales. Se admite también la iniciativa ciudadana para convocar referéndum, en los términos que prevé la ley (nuevo art. 240). Finalmente, por lo que se refiere a los deberes, hay que reseñar la desconstitucionalización del deber militar. Se trata de una medida que conecta con la orientación dominante en los países de nuestro entorno, tendente a la profesionalización de las FF.AA., pero que en Portugal tiene una especial significación dado el papel determinante que jugaron las FF.AA. en el nacimiento del régimen constitucional.

El grueso de la revisión constitucional de 1997 tiene como objeto la reordenación del sistema institucional portugués. Así se desprende del propio Acuerdo político PS-PSD, al que se ajusta el legislador constitucional de $1997^{95}$, que fija expresamente como objeto de la revisión: "la necesaria modernización del sistema político, la profundización de la democracia representativa, la revalorización del papel de los ciudadanos en la vida política nacional, incluidos los que residen en el extranjero, las indispensables reformas en la organización de la Justicia, la Administración pública y la Defensa».

Dentro de la reordenación del sistema institucional, merecen especial atención las medidas adoptadas por el legislador constitucional de 1997 tendentes a reforzar el papel de la Asamblea de la República. Se trataba de hacer frente al proceso de pérdida progresiva de poderes efectivos de decisión de la institución parlamentaria en beneficio de las instancias ejecutivas (incluso en el terreno específicamente legislativo) y también, últimamente, de las instancias supraestatales europeas. En definitiva, se trataba de defender la centralidad parlamentaria, seriamente amenazada - no sólo en Portugal, también en los países del entorno; entre ellos, también el nuestro- por la reciente evolución institucional y la creciente presión sobre la institución parlamentaria de otras instancias institucionales ${ }^{96}$.

95 Un amplio comentario sobre este acuerdo bipartito PS-PSD pude verse en P. OtERo: O Acordo de revisao constitucional: significado político e jurídico, Lisboa, 1997.

${ }^{96}$ Vid. A. BARRETO: "Assembleia da República: uma instituiçao subalternizada», RISCO, 1990, pp. 101 y ss. 
De acuerdo con estos criterios, el legislador constitucional de 1997 va a ampliar las competencias legislativas de la asamblea de la República mediante el ensanchamiento del área reservada al poder legislativo, en la doble modalidad, según la Constitución portuguesa, de reserva relativa - competencias legislativas de la A.R. salvo autorización al Gobierno (art. 165) - o de reserva absoluta - competencias legislativas exclusivas de la A.R. sin posibilidad de delegación al Gobierno (art. 164)—; sobre todo en esta última modalidad, que queda notablemente incrementada con la inclusión de un amplio listado de nuevas materias que abarcan desde el ámbito autonómico, local y europeo al régimen de las fuerzas de seguridad y los servicios de apoyo al Presidente de la República.

Por otra parte, se amplia también el ámbito material de las leyes orgánicas (art. 166.2) —ciudadanía, partidos políticos, Asambleas autonómicas y normativa financiera autonómica, órganos locales y regiones administrativas, secretos de Estado y servicios de inteligencia-. Asimismo, se ensancha igualmente el ámbito de las leyes reforzadas - se exige para su aprobación una mayoría cualificada de dos tercios que suponga, al menos, la mayoría absoluta de los diputados de la Asamblea- extendiéndole a la legislación sobre el derecho de sufragio de los electores portugueses en el extranjero en las elecciones presidenciales, sobre la determinación del número de miembros de la Asamblea y sobre la elección de los órganos de gobierno local ${ }^{97}$. En todos los casos, ello comporta una reafirmación del papel del Parlamento en el sistema institucional. Como también contribuyen a esta reafirmación parlamentaria las nuevas competencias, asumidas como consecuencia de la revisión que comentamos, en relación con la Unión Europea: pronunciamiento preceptivo de la Asamblea de la República sobre las materias pendientes de decisión en los órganos de la U.E. que incidan en la esfera de su competencia legislativa (nuevo al. n/ del art. 161); participación de Portugal en el proceso de construcción de la U.E. (nuevo n. ${ }^{\circ} 6$ del art. 163) y régimen de designación de los miembros de los órganos comunitarios europeos, con excepción de la Comisión (nuevo al. p/ del art. 164).

Otras modificaciones hacen referencia a la ampliación del periodo de sesiones de la asamblea de la República (art. 174.1), anticipando su

97 Sobre el tratamiento de estas cuestiones en la revisión de 1997, vid. J. BARCELAR GouveIA: "The Fourth Revision of the Portuguese Constitution", ERPL, op. cit., pp. 214 y ss. Más ampliamente sobre las leyes orgánicas y reforzadas, vid. L. M. SIlva: Da Lei Orgânica na Constituçao Portuguesa, 1991; C. BLANCO DE MoRAIS: As leis reforçadas, Coimbra, 1998. 
inicio en un mes (del 15 de Octubre al 15 de Septiembre), la reducción del número de diputados: entre 180 y 230 (art. 148) y la posibilidad de que junto a las circunscripciones territoriales plurinominales, y la nacional, existan también las uninominales (art. 149.1).

En conjunto, las modificaciones introducidas por el legislador constitucional de 1997 tienden a un reforzamiento del Parlamento $y$, en consecuencia, operan en el sentido de una parlamentarización del sistema político ${ }^{98}$. Hay que puntualizar, de todas formas, que la tendencia a la parlamentarización del sistema -originariamente, un semipresidencialismo atípico- se venía dando desde la rectificación institucional de la primera revisión de 1982, como consecuencia de la propia dinámica institucional. En este contexto, la cuarta revisión de 1997 no hace sino dar carta de naturaleza constitucional al proceso que se venía desarrollando en la última década y media (1982-1997).

Manteniendo la configuración constitucional de la Judicatura (Tit. V) en los términos ya establecidos por el texto originario y la dos primeras revisiones, la de 1997 va a introducir algunas modificaciones que contribuyen a una reordenación actualizada de la organización judicial. La más importante es la supresión de los Tribunales Militares en la estructura judicial (art. 209); salvo en situación de estado de guerra, en la que "los Tribunales militares tendrán competencia para juzgar delitos de naturaleza estrictamente militar" (art. 213). No obstante, se admite la presencia de uno o más jueces militares, conforme a lo dispuesto por la ley «en los casos en que se juzguen delitos de naturaleza estrictamente militar» (art. 211). Ello significaba la culminación del proceso de normalización civil (en este caso en el ámbito judicial), una vez superada por completo la excepcional coyuntura político-militar del periodo constituyente.

Otra de las modificaciones dignas de reseñar, ésta en el ámbito específico de la abogacía, es la constitucionalización expresa de "las inmunidades necesarias para el ejercicio de su mandato" (art. 208) como elemento esencial para la administración de la justicia. Así mismo, y en otro orden, referido a la composición del Consejo Superior de la Magistratura ${ }^{99}$, cabe reseñar la ligera variación que supone la plena libertad del Presidente de la República para nombrar los dos miembros

98 Sobre la evolución del semipresidencialismo portugués, vid. C. BLANCO DE MoRAIS: "La metamorfosi dei semipresidenzialismo portoghese", en AA.VV. ( a cura de L. Pegoraro e A. Rinella): Semipresidenzialismi, Padua, 1997, pp. 125 y ss.

99 Sobre el Consejo Superior de la Magistratura después de la revisión constitucional de 1997, vid. J. MIRANDA: "Le Conseil Superieur de la Magistratura", Revue Européenne de Droit Public, Vol. 11, n. ${ }^{\circ}$, 1999. 
que le corresponden de ese órgano sin ningún condicionante (hasta entonces, uno de ellos tenía que ser Magistrado de la carrera judicial).

Por último, por lo que se refiere al Tribunal Constitucional, instituido como ya sabemos por la primera revisión (1982) que cubría así la importante laguna institucional del constituyente de 1976, se mantiene su configuración constitucional sin apenas alteraciones de relieve. En este sentido, cabe reseñar la ampliación (y la simultánea limitación) del periodo de mandato de sus integrantes, de seis a nueve años, no renovable; o la alusión expresa a las inmunidades que la ley deberá establecer en el Estatuto de los Magistrados del T.C.. Por otra parte, y en sintonía con la atención creciente que el legislador constitucional dedica al tema regional, se amplían las competencias del T.C. a la verificación de la constitucionalidad de los referéndums regionales (junto a los nacionales y locales, ya contemplados). Asimismo, se amplían también sus competencias en materia electoral, resolviendo los recursos e impugnaciones que puedan plantearse en relación con las elecciones a la Asamblea de la República o a las Asambleas legislativas regionales. (nuevos al. g) y h) del art. 223) ${ }^{100}$.

\section{La revisión de 2004. Continuidad con 1997 y nuevas correcciones. Las autonomías regionales.}

La sexta revisión constitucional (2004) puede considerarse, tanto por su carácter como por su contenido, como una continuación de la obra revisora del legislador constitucional de 1997. Al igual que ésta, se trata de una revisión ordinaria y, así mismo, el grueso de las modificaciones introducidas afectan, en distinta medida, a diversas cuestiones relativas a los derechos y libertades y a la organización institucional, sin que pueda afirmarse, como también ocurría con la cuarta revisión de 1997, que haya una idea fuerza dominante en torno a la cual se articula el conjunto de la revisión. En líneas generales, puede decirse que se trata de continuar la obra de reordenación y remodelación constitucional emprendida por el legislador constitucional en 1997, si bien con un alcance más limitado que en aquella ocasión ${ }^{101}$.

100 Para un estudio más amplio sobre la evolución de la justicia constitucional, vid. G. VAGLI: L'evoluzione del sistema di giustizia costituzionale in Portogallo, Pisa, 2001.

101 Un amplio comentario, de carácter general, sobre esta revisión puede verse en R. OrRÙ: "La VI Revisao della Costituzione portoghese del 1976: della scelta "minimalista" al risultato altamente "problemático" ", Diritto Pubblico Comparato ed Europeo, 2005-III, pp. 1136 y ss. Asimismo, J. MAGALHAES: "Uma revisao cirurgica e funda, no tempo certo", en AA.VV. (MAgalhaES, org.): Constituiçao da República Portuguesa, Publico Comunicaçao Sociale, Lisboa, 2004. 
En términos cuantitativos, la sexta revisión de 2004 afecta a cuarenta y una disposiciones constitucionales, la gran mayoría de ellas ubicadas en la Parte primera (derechos y libertades) y la Parte tercera (organización institucional). Así mismo, y siguiendo la costumbre, muy discutible desde el punto de vista de la claridad y de la seguridad jurídicas, de sus predecesoras (muy especialmente la de 1997), renumera buena parte de las disposiciones modificadas. Finalmente, las disposiciones transitorias con las que se cierra esta nueva ley constitucional ${ }^{102}$, difieren la vigencia efectiva de algunas de las previsiones contenidas en ella -Alta autoridad para la comunicación social, nuevas funciones de las Ministros de la República, competencias legislativas de las Regiones autónomas y legislación electoral para las Asambleas legislativas autonómicas- al cumplimiento de las condiciones que se especifican.

Por lo que se refiere al respaldo político con que contó esta (sexta) revisión constitucional, hay que constatar, una vez más, el apoyo de las dos principales formaciones políticas portuguesas - PS y PSD- ampliable también en esta ocasión, como en casi todas las revisiones, al CDS-PP, lo que proporciona los votos suficientes para sobrepasar ampliamente la mayoría de 2/3 exigida para aprobar la revisión constitucional. $Y$ también, como en todas las demás ocasiones, esta revisión contó con la oposición del Partido Comunista Portugués (PCP), a la que hay que añadir la del Bloque de Izquierda (BE) y los Verdes (PEV) ${ }^{103}$.

En cuanto al contenido de la revisión constitucional, cuatro son los elementos que pueden ser reseñados en ella: la adecuación de Portugal al desarrollo del proceso de integración europea (arts. 7 y 8); los retoques en la regulación de algunos derechos y en algunos aspectos de la organización institucional, con mención especial a la nueva regulación de la comunicación social (arts. 39 y 163) y a los límites en la renovación sucesiva de los cargos públicos ejecutivos (art. 118); y lo más importante en esta revisión: los cambios introducidos en materia de organización autonómica y, en particular, en el régimen autonómico de Azores y Madeira.

En materia de derechos y libertades cabe reseñar la introducción, de acuerdo con la evolución de las concepciones sobre la materia en los últimos años, de una referencia expresa a la orientación sexual como

102 Lei Constitucional n. ${ }^{\circ}$ 1/2004 (Diário da República, I Serie A, de 24 de Julio de 2004.

103 En la votación final del pleno de la Asamblea de la República, votaron a favor 183 diputados. 95 del PSD, 75 del PS y 13 del CDS-PP; en contra votaron 14 diputados: 8 del PCP, 3 del BE, 2 del PEV (verdes) y 1 del PS. 
posible causa de discriminación (art. 13.2). Por otra parte, y en relación con la extradición (art. 33), que ya había sido objeto de una importante reformulación en la cuarta revisión (1997), se matizan ahora las condiciones para que las autoridades portuguesas puedan acceder a una petición en este sentido por parte de un Estado extranjero; ello sólo será posible si el Estado requirente también forma parte de la Convención internacional a la que está vinculado Portugal (art. 33.4).

Una novedad destacable en la revisión que comentamos es la reformulación de la protección del derecho a la información y libertad de prensa en los medios de comunicación social, que se confía a una autoridad administrativa independiente (art. 39) ${ }^{104}$ cuya composición, competencias, organización, funcionamiento y estatuto de sus miembros se remite a una ley que tiene la particularidad de ser aprobada por una mayoría reforzada de dos tercios de los diputados presentes que, en todo caso, deben representar la mayoría absoluta de todos los diputados de la Asamblea de la República. (art. 168.6). Además, la propia Constitución se ocupa directamente de prever la elección, por las mismas mayorías, de los miembros de esta entidad (art. 163.h), lo que da cuenta de la importancia que el legislador constitucional de 2004 da a este órgano.

Otra de las novedades a reseñar, también en el ámbito de la remodelación institucional que caracteriza esta revisión, es la previsión del legislador constitucional sobre la posibilidad de limitación de la renovación sucesiva de mandatos de titulares de cargos políticos ejecutivos. Hay que llamar la atención sobre el hecho de que el legislador constitucional prevé la posibilidad pero no la obligación de la limitación (art. 118.2). Por otra parte, la ley que, en su caso, limite la sucesión de mandatos de los cargos políticos ejecutivos ha de ser aprobada por las mayorías reforzadas ya referidas (art. 168.6).

Las novedades más importantes, sin embargo, de esta sexta revisión, se refieren a las autonomías regionales. Aunque esta cuestión tiene un peso muy limitado en el proceso político portugués (en nada comparable con el que tiene en España) ha venido mereciendo una progresiva atención en algunos círculos políticos que, finalmente, ha acabado trasladándose al legislador constitucional. En este sentido, la revisión constitucional que comentamos es la que mayor atención relativa presta a esta cuestión; y también en este tema -la reorganización autonómica del Estado- la revisión constitucional de 2004 va ser continuadora de la precedente revisión de 1997.

104 Vid R. OrRù, op. cit., p. 1142. 
Ya el texto originario de 1976 dedicaba un Título específico (Tit. VII de la Parte tercera, arts. 227-236) a las Regiones autónomas, estableciéndose un régimen autonómico muy limitado, de carácter básicamente administrativo, para las Azores y Madeira. Las dos primeras revisiones constitucionales (1982 y 1989) introdujeron una serie de modificaciones, sin que ninguna de ellas afectase de forma esencial al esquema originario de autonomía limitada. En el conjunto de las amplias, y profundas, revisiones constitucionales de 1982 y 1989, la cuestión autonómica-regional ocupa un lugar muy secundario ${ }^{105}$.

El legislador constitucional de 1997 vuelve a ocuparse del tema, lo que muestra que aunque no haya sido en ningún momento una cuestión central del proceso político (a diferencia de lo que ocurrido en España) sí ha merecido, de forma continuada, la atención del legislador constitucional. La cuarta revisión, de 1997, apunta hacia una ampliación progresiva del ámbito autonómico, especialmente en el ámbito legislativo, lo que confiere una nueva dimensión, más amplia, a la limitada autonomía de las regiones portuguesas. Hasta tal punto que en algunos círculos doctrinales se ha considerado (a nuestro juicio, de forma completamente exagerada) esta ampliación de la autonomía legislativa regional, nada menos que como una "quiebra de la unidad legislativa de la República» ${ }^{106}$. La plasmación de esta nueva concepción, más amplia, de la autonomía regional es el nuevo enunciado del art. 228 (antes 230), que define en positivo el ámbito de la autonomía legislativa y administrativa regional (donde antes se definían sólo los límites y las prohibiciones de las regiones autónomas).

Con este precedente inmediato, el legislador constitucional de 2004 continúa avanzando en el camino de la ampliación del ámbito competencial autonómico regional. En este sentido, se amplían las competencias legislativas de las Regiones autónomas, eliminando la referencia al interés específico regional como criterio justificativo de los

105 Sobre este tema, vid. A. FerReIRA: As Regioes Autonomas na Constituiçao Portuguesa, Coimbra, 1980; J. MIRANDA: "Le Regioni autonome portoghesi», en Le Región, 1986, pp. 1042 y ss; en particular, sobre el tratamiento de este tema en anteriores revisiones, vid. A. VITORINO: Os poderes legislativos das regioes autonomas na segunda revisao constitucional, Lisboa, 1992.

106 J. J. Gomes Canotilno: Direito Constitucional ..., op. cit., p. 213. Sobre el sistema autonómico portugués tras la revisión de 1997, vid. C. BLANCO DE MoRAIS: "Portogallo: requiem per il regionalismo amministrativo», Quaderni costituzionali, 1999, p. 419; V. PIERGIGLI: «Il decentramento territoriale nell'ordinamento portoghese», en AA.VV. (S. GAMBINO, cura): Stati nazionali e poteri locali. Esperienze straniere e tendanze attuali in Italia, Rimini, 1998, p. 1039; A. X. LÓPEZ MIRA: "La regionalización en Portugal», Revista de las Cortes Generales, n. ${ }^{\circ}$ 53, 2001, pp. 111 y ss. 
decretos legislativos regionales (normas legislativas regionales). En la nueva redacción del $n .^{\circ} 4$ del art. 112, los decretos legislativos regionales pueden versar sobre cualquier materia enunciada en su propio Estatuto (sin necesidad de invocar ningún interés específico regional), con el único límite de las materias reservadas a los órganos de soberanía. Pero incluso este límite es relativizado, ya que se admite la posibilidad de que las Regiones autónomas legislen «en materias de reserva relativa de la Asamblea de la República, mediante autorización de ésta" (art. 227.1.b), si bien con las excepciones que a continuación prevé esta misma disposición. También se suprime la referencia a los principios fundamentales de las leyes generales de la República como marco en el que han de encuadrarse los decretos legislativos regionales, que podrán ser autorizados por la Asamblea de la República en los mismos términos que la normativa autorizada al Gobierno (arts. 112.4 y 228.1).

Por lo que se refiere a los órganos autonómicos regionales, y en particular al más importante, la Asamblea legislativa, se refuerzan sensiblemente su protección y garantías constitucionales ${ }^{107}$. Así, se suprime la referencia existente antes de esta revisión a la posibilidad de disolución de las Asambleas legislativas regionales por el Presidente de la República "por iniciativa propia o a propuesta del Gobierno" (art. 133.j) en el supuesto de comisión de "actos graves contrarios a la Constitución" (art. 234.1), sustituyendo este procedimiento por otro equiparable (con las debidas adaptaciones) al seguido para la eventual disolución de la Asamblea de la República, previa audiencia del Consejo de Estado y de los partidos con representación en la Asamblea Regional (nueva redacción del art. 133.j y del art. 234.1).

Una novedad digna de reseñar es la introducción del referéndum de ámbito regional (nuevo n. ${ }^{\circ} 13$ del art. 115), de carácter vinculante, "sobre cuestiones de relevante interés específico regional» (art. 232.2). La decisión de convocar referéndum regional corresponde al Presidente de la República a propuesta de la Asamblea legislativa de la Región autónoma.

En las relaciones con el Estado, la figura del Ministro de la República - representante del Estado en la Región autónoma- es reconfigurada pasando a tener la nueva denominación de Representante de la República, que apunta hacia una desgubernamentalización del cargo. Nombrado y separado del cargo por el Presidente de la República "oído el Gobierno" (antes, a propuesta del Gobierno), se redefinen

107 Vid. R. OrRù: "La VI Revisao ...", op. cit., pp. 1143 y ss. 
sus funciones, privándole de las competencias que antes ostentaba en materia de supervisión de los servicios del Estado en la Región (antiguo $n .{ }^{\circ} 3$, ahora suprimido, del art. 230).

Finalmente, en el terreno de las relaciones con la Unión Europea, la revisión de 1997 introduce una referencia expresa a la posibilidad de que la transposición de los actos jurídicos de la U.E. al ordenamiento jurídico interno portugués pueda realizarse mediante decreto legislativo regional (además de mediante ley o decreto-ley estatales) (art. 112.8).

Las modificaciones introducidas por la revisión constitucional de 2004 (continuación de las de la cuarta revisión de 1997) son muy significativas en cuanto a la evolución que experimenta el régimen autonómico portugués ${ }^{108}$. Partiendo de un modelo autonómico de carácter básicamente administrativo, ha ido adquiriendo progresivamente perfiles que tendencialmente le aproximan a un régimen de autonomía política para las Regiones de Azores y Madeira.

\section{LA READECUACIÓN CONSTITUCIONAL AL CAMBIANTE MARCO INTERNACIONAL. LAS REVISIONES DE 1992, 2001 Y 2005.}

Las tres revisiones constitucionales que restan por examinar (1992, 2001 y 2005) tienen como eje la inserción de Portugal en el cambiante marco internacional; $y$, más en particular, en el proceso de integración europea. A diferencia de las revisiones examinadas hasta ahora, las tres de las que vamos a tratar a continuación tienen como característica común la limitación de su objeto, relacionado en todos los casos con cuestiones de orden supraestatal ${ }^{109}$. Aunque en términos cuantitativos, por lo que se refiere al número de disposiciones constitucionales afectadas, no tienen la dimensión de las vistas hasta ahora, sin embargo, su interés no debe pasar desapercibido ya que reflejan con toda nitidez el influjo de uno de los factores más característicos de nuestro tiempo como es la importancia creciente de los marcos internacionales, muy especialmente del europeo en nuestro caso, y su incidencia en el plano constitucional.

108 Vid. R. OrRÙ: "L'istituzione in concreto delle Regioni amministrative in Portogallo negata per referéndum: una partita chiusa?", Diritto Pubblico Comparato ed Europeo, 1999, pp. 220 y ss.; C. BLANCO DE MORAIS: "Portogallo. Réquiem per il regionalismo administrativo", Quaderni Costituzionali, 1999, pp. 419 y ss.

109 En concreto, se trata de la inserción de Portugal en el proceso de integración europea, de la internacionalización de la justicia penal y de la ubicación de Portugal en el nuevo marco constitucional (hoy frustrado) de la Unión Europea. 
Como características comunes y distintivas de estas tres revisiones constitucionales es preciso reseñar su carácter extraordinario, de acuerdo con la tipología de las modalidades de revisión que contempla la Constitución portuguesa (las otras cuatro revisiones tenían, todas ellas, carácter ordinario); y, así mismo, la brevedad en cuanto a su extensión y número de disposiciones afectadas (en contraste con la desmesurada extensión de las revisiones examinadas en los párrafos precedentes). Por último, las tres revisiones de las que vamos a ocuparnos a continuación tienen su origen en sendos Tratados internacionales ${ }^{110}$ que exigen, o al menos aconsejan a juicio de la Asamblea de la República, una revisión constitucional con el fin de adecuar la Constitución nacional a la nueva y cambiante realidad internacional.

\section{La revisión de 1992. La constitucionalización de la inserción de Portugal en la UE.}

La inserción de Portugal en el proceso de integración europea ha venido siendo objeto de atención creciente por parte del legislador constitucional portugués. Hay que partir del hecho de que Portugal (como también España) ha ocupado históricamente una posición periférica -no sólo geográficamente sino también políticamente- en relación con Europa; agravada además en épocas recientes por la prolongada persistencia de un régimen dictatorial que retrasó el acceso a la vida constitucional (al igual que en España, y también en Grecia) hasta mediados de la década de los setenta. Va a ser precisamente la instauración del régimen constitucional en Portugal lo que abre el camino a su inserción en el proceso de integración europea ${ }^{111}$; hecho que tendrá su reflejo también en su evolución constitucional.

No hay ninguna alusión expresa al proceso de integración europea en el texto originario de la Constitución portuguesa. Hay que recordar que en 1976 las Comunidades Europeas (CC.EE.) no pasaban de conformar un incompleto mercado común (denominación con la que se conocía entonces a la Europa comunitaria), que no era objeto tampoco de

110 Tratado de la Unión Europea de Maastricht (1992) con las modificaciones introducidas en Ámsterdam (1997) y Niza (2001); Tratado de Roma (1998) por el que se instituye el Tribunal Penal Internacional y Proyecto de Tratado por el que se instituye una Constitución para Europa.

111 La cuestión europea y sus implicaciones constitucionales empiezan a plantearse desde los primeros momentos de la entonces recién estrenada vida constitucional portuguesa; en este sentido, vid. M. ${ }^{a}$ I. JALLES: Implicaçoes jurídico-constitucionais da adesao de Portugal as Comunidades Europeias, Lisboa, 1980. 
referencias constitucionales en ninguno de los países que integraban entonces las CC.EE.; éstas empezarán a aparecer a medida que va desarrollándose el proceso de integración europea y la Europa comunitaria deviene no sólo una comunidad económica sino también una comunidad de derecho ${ }^{112}$.

Las dos primeras revisiones constitucionales de los años ochenta empiezan ya a introducir referencias al proyecto europeísta. La primera de ellas (1982) hace una alusión, aunque no de forma explícita, a la Europa comunitaria, previendo la aplicación directa en el ámbito interno de las normas emanadas de los órganos competentes de las organizaciones internacionales de las que forme parte Portugal, si así se establece en los respectivos Tratados constitutivos (nuevo n. ${ }^{\circ} 3$ del art. 8). Es evidente que las normas y los órganos a los que se hace referencia en esta nueva disposición introducida por el legislador constitucional de 1982 sólo pueden ser los comunitarios. Incluso la referencia a los Tratados constitutivos es esclarecedora ya que es la denominación con la que se conocen los Tratados que dan lugar al nacimiento de las Comunidades Europeas.

La segunda revisión (1989) se pronuncia ya en términos explícitos a favor del proyecto europeísta, comprometiéndose a reforzar la identidad europea (nuevo n. ${ }^{\circ} 5$ del art. 7 , dedicado a las relaciones internacionales). Cabe reseñar los términos contundentes en que está formulado el compromiso europeísta portugués - "Portugal empenha-se no reforço da identidade europeia...»- que, como anota M. Daranas, "constituye toda una declaración programática europeísta que apenas encuentra equivalencia en los textos constitucionales de los restantes Estados miembros de las CC.EE." ${ }^{113}$.

Pero será en la tercera revisión constitucional (1992), que tiene su origen en la firma por Portugal del Tratado de la Unión Europea de Maastricht, cuando se introducen los elementos constitucionales más relevantes en relación con la integración europea. Esta tercera revisión es la primera de carácter extraordinario (es precisamente esta revisión la que formaliza constitucionalmente la modalidad extraordinaria de re-

112 Es decisiva, a este respecto, la intervención del Tribunal de Justicia de las Comunidades Europeas, que va a ir definiendo progresivamente los perfiles jurídicos y constitucionales de la Europa comunitaria; tema que desarrollo más ampliamente en mi trabajo "La constitucionalización de la Unión Europea", en AA.VV. (J. CoRCUERA, coord.): La protección de los derechos fundamentales en la UE, Dykinson, 2002, pp. 627 y ss. 1989.

M. DARANAS: Nota (13) al art. 7; Boletín de Legislación Extranjera, n. ${ }^{\text {os }}$ 96-97, 
visión) y tiene como único objetivo la adecuación de la Constitución portuguesa al recién firmado Tratado de la Unión Europea. En esta ocasión, la revisión constitucional portuguesa coincidió temporalmente con las realizadas en otros países, también miembros de la U.E., con la misma finalidad ${ }^{114}$.

En la misma línea europeísta ya trazada por el legislador constitucional de 1989 (y antes por el de 1982), la tercera revisión (extraordinaria) de $1992^{115}$ avanza sensiblemente mediante la constitucionalización expresa de la noción de "construcción de la Unión Europea». Ya no se trata sólo de una referencia genérica a la identidad europea sino de formalizar un compromiso constitucional con la Unión Europea, ente con personalidad jurídica definida, en los términos establecidos por el Tratado que acaba de instituirla (Maastricht, 1992). Y precisamente para conseguir ese objetivo constitucional -la construcción de la U.E.- - Portugal se compromete al máximo nivel (el constitucional) a "convenir el ejercicio en común de los poderes necesarios" a tal fin. Interesa subrayar la referencia al "ejercicio en común de poderes", que trasciende la mera coordinación intergubernamental de políticas y que representa la expresión más completa de la integración europea. Hay que puntualizar que el "ejercicio en común de los poderes" está enmarcado por el legislador constitucional dentro de los principios de reciprocidad y subsidiariedad, "teniendo presente la realización de la cohesión económica y social" (nuevo n. ${ }^{\circ} 6$ del art. 7).

Teniendo en cuenta que el Tratado de la Unión Europea incide de Ileno, en palabras de Gomes Canotilho, en el núcleo esencial de la estatalidad, la previsión constitucional de «ejercer en común los poderes necesarios para la construcción de la Unión Europea» afecta a la propia estructura constitucional; muy especialmente en el ámbito específico de la Constitución económica. En este sentido, no faltan quienes, en particular desde círculos doctrinales, advierten sobre el riesgo de desnacionalización de la Constitución portuguesa, que pasaría a ocupar un lugar, en relación con la U.E., similar al de las Constituciones de los

114 Los textos de las leyes constitucionales modificando las respectivas Constituciones (Alemania, Francia, Bélgica ...) acompañados de un estudio introductorio de P. PÉREZ TREMPS sobre las implicaciones constitucionales de la ratificación, por los Estados miembros, del Tratado de la Unión Europea de Maastricht, pueden verse en Boletín de Legislación Extranjera, n. ${ }^{\circ}$ 147-148, 1994 (monográfico sobre el Tratado de la Unión Europea y sus consecuencias constitucionales), Cortes Generales, Madrid, 1994.

${ }^{115}$ Lei Constitucional n. ${ }^{\circ}$ 1/1992 (Diário da República, I Serie A, n. ${ }^{\circ} 273$ de 25 de Noviembre de 1992). 
Estados miembros en el seno de un Estado federal. Eventualidad que, como puntualiza seguidamente el propio autor de referencia, no es plausible en el momento actual, mientras los Estados sigan siendo "dueños del tratado»"116.

Otra de las novedades importantes que introduce el legislador constitucional de 1992 es la constitucionalización expresa de la noción de ciudadanía europea (art. 15), que a partir de ese momento y en los términos previstos en el Tratado de la U.E., va a coexistir, al igual que en los demás países de la U.E., con la ciudadanía nacional. De acuerdo con esta ampliación transfronteriza, a escala europea, del ámbito de la ciudadanía, se reconoce constitucionalmente el derecho de sufragio activo y pasivo, en condiciones de reciprocidad, en las elecciones municipales y europeas, a los ciudadanos eurocomunitarios. El reconocimiento de estos nuevos derechos electorales, así como la introducción de la nueva noción de ciudadanía europea (con plasmación constitucional expresa en Portugal) venían exigidos por el Tratado de Maastricht, suscrito por la República portuguesa (junto con los restantes once miembros, en aquél momento, de la U.E).

La constitucionalización del Banco de Portugal, al que se dedica una disposición específica (art. 105), obligaba a su modificación, dados los profundos cambios que en esta materia, más que en ninguna otra, introducía el Tratado de la Unión Europea, cuyo elemento esencial era precisamente la instauración de la Unión Económica y Monetaria (UEM) y, en consecuencia, la creación de las instancias necesarias para la consecución de ese objetivo: el Sistema Europeo de Bancos Centrales (SEBC) y el Banco Central Europeo (BCE). Ello obligaba a la reubicación de los Bancos Centrales de los Estados miembros en el nuevo sistema bancario europeo - SEBC y BCE- diseñado en el Tratado de la U.E. ${ }^{117}$. En sintonía con el nuevo esquema de Maastricht, el Banco de Portugal va a sufrir una profunda reconfiguración institucional en los términos que fija el legislador constitucional portugués de 1992.

Hay que reseñar, como rasgos más característicos de la nueva regulación constitucional sobre la materia, la desvinculación del Banco de Portugal del Gobierno, lo que tiene su reflejo en la eliminación de la referencia alusiva a colaboración con las directrices del Gobierno, así

116 J. J. Gomes Canotilho: Direito Constitucional ..., op. cit., p. 211, en referencia a la conocida Sentencia del Tribunal Constitucional alemán de 12 de Octubre de 1993

117 Tit. VII: Política Económica y Monetaria, del Tratado de la Comunidad Europea (TCE). 
como a la ejecución de las políticas monetaria y financiera conforme a lo dispuesto en la Ley de Presupuestos y los objetivos definidos en los planes, tal y como se determinaba en la anterior redacción del art. 105. Paralelamente a esta desvinculación del Gobierno, al igual que el resto de los Bancos Centrales de los Estados miembros, se produce una vinculación con el BCE y el SEBC, a los que se confía, a partir de Maastricht, la elaboración de la política monetaria y financiera y con los que habrá de colaborar el Banco de Portugal en la ejecución de la política monetaria, según la nueva redacción del art. 105.

La tercera revisión constitucional de $1992^{118}$ se completa con dos pequeñas modificaciones relativas al seguimiento y valoración que la Asamblea de la República ha de hacer de "la participación de Portugal en el proceso de construcción de la Unión Europea» (nuevo al. f/ del art. 166); y, en conexión con éste, el establecimiento de la obligatoriedad para el Gobierno de proporcionar a la Asamblea de la República la información necesaria referente al proceso de construcción de la U.E. (nuevo al. i/ del art. 200).

Finalmente, y al margen de las modificaciones relacionadas con el Tratado de la Unión Europea, en torno al cual gira esta revisión, se constitucionalizan expresamente las dos modalidades de revisión constitucional -ordinaria y extraordinaria- y los supuestos en los que procede recurrir a una u otra modalidad. En realidad, lo único que se hace es formalizar constitucionalmente, mediante la distinción entre las revisiones ordinarias y extraordinarias (términos nuevos introducidos en esta revisión) la situación ya existente que admitía la posibilidad de que la Asamblea de la República asumiese en cualquier momento, sin esperar a que transcurra el plazo de cinco años desde la última revisión, poderes extraordinarios de revisión constitucional por una mayoría especial y cualificada de 4/5; ahora denominada extraordinaria por oposición a la forma normal y ordinaria de modificar la Constitución. Esta es precisamente la modalidad que se estrena en esta tercera revisión (1992) y que posteriormente va a volver a utilizarse en la quinta y séptima revisiones constitucionales (2001 y 2005), de las que nos ocuparemos a continuación.

118 Comentarios de carácter general sobre esta tercera revisión pueden verse en G. D'Oliveira Martins: "Europa e Constituiçao. A Revisao Constitucional de 1992", Estado \& Direito, n. ${ }^{\circ} 11,1993 ;$ J. MiRANDA: "La Constitution portugaise et le Traité de Maastricht", Revue Française de Droit Constitutionnel, n. ${ }^{12}$, 1992; G. VAGLI: Sulla terza revisione costituzionale della II Repubblica Portoghese, Pisa, 1994. 


\section{La revisión de 2001. La constitucionalización} de la internacionalización de la justicia penal

Al igual que en la tercera revisión constitucional (1992), en 2001 la Asamblea de la República decidió asumir, por segunda vez, poderes extraordinarios de revisión, de acuerdo con el art. 284.2 (introducido precisamente en esa revisión de 1992) para efectuar la quinta revisión constitucional (la cuarta había tenido lugar en 1997, sin que hubiese transcurrido todavía el plazo preceptivo de cinco años para la revisión ordinaria). Esta asunción de poderes extraordinarios de revisión se justificaba por "la necesidad, con carácter urgente, de despejar los obstáculos que la Constitución de la República portuguesa, en su versión vigente, opone a la aprobación por la Asamblea de la República del Tratado de Roma que instituye el Tribunal Penal Internacional (TPI)». De acuerdo con el pronunciamiento de la propia Asamblea de la República, no era aconsejable "esperar a la próxima revisión ordinaria, aun lejana y necesariamente lenta» ${ }^{119}$.

Si bien el objeto inicial de la quinta revisión de 2001, y lo que justificaba su carácter extraordinario, era exclusivamente la ratificación por Portugal del Estatuto de Roma sobre el TPI, en el curso del proceso de revisión se fueron incorporando otras materias no previstas inicialmente (a las que nos referiremos más adelante), cuya inclusión en una revisión con carácter extraordinario resulta dudosa; ello lleva a algunos comentaristas a expresar sus reservas, al detectar, en palabras de Gomes Canotilho, "una transmutación de la extraordinariedad de la revisión en momento de barganha de posiciones constitucionales, perturbando la distinción entre revisiones ordinarias y extraordinarias» ${ }^{120}$. En cualquier caso, el texto final de la revisión fue aprobado por la asamblea de la república (4 Octubre 2001) por amplia mayoría, con el voto favorable del PS, PSD y el CDS-PP, y con la oposición del PCP, EV y BE.

Al igual que la revisión extraordinaria de 1992 (y también, como se verá a continuación, de la de 2005) y a diferencia de las cuatro revisiones ordinarias de 1982, 1989, 1997 y 2004, se trata de una revisión breve, que afecta tan sólo a seis disposiciones constitucionales ${ }^{121}$. El ele-

119 Resolución 27/2001 de la Asamblea de la República (Diário da República, I, A, n. ${ }^{\circ} 80$, de 4 de Abril de 2001) aprobada con los votos favorables de PS, PSD y CDSPP y contrarios de PCP, BE y verdes.

120 J. J. Gomes Canotilho: Direito Constitucional..., op. cit., p. 214.

121 Lei Constitucional 1/2001 (Diário da República, I Serie A, n. ${ }^{\circ}$ 286, de 12 de Diciembre de 2001). Para un comenario sobre el conjunto de esta revisión, vid. J. BAR- 
mento esencial de esta revisión, y causa originaria de la misma, es la cobertura constitucional que proporciona a la internacionalización de la justicia, a través del recién creado Tribunal Penal Internacional (TPI), en los términos previstos en el Estatuto de Roma. Hay que indicar que también otros países firmantes de este Tratado han efectuado reformas constitucionales similares con el mismo fin.

La revisión efectuada se limita a añadir un nuevo apartado ( $\left.n .{ }^{\circ} 7\right)$ al art. 7, por el que la República portuguesa se compromete a «aceptar la jurisdicción del Tribunal Penal Internacional, en las condiciones de complementariedad y demás términos establecidos en el Estatuto de Roma» con el fin, según los propios términos en que se expresa la Resolución de la Asamblea de la República al respecto, de contribuir al «combate a nivel supranacional contra los crímenes más graves que afectan a la Humanidad, en un marco de afianzamiento de la tutela internacional de los Derechos del Hombre". La fórmula genérica empleada en el nuevo art. 7.7 permitía incluir en ella cualquier cuestión relacionada con el ámbito reservado al Tribunal Penal Internacional por el Estatuto de Roma.

Aunque esta era, en exclusiva, la finalidad de la revisión constitucional extraordinaria prevista inicialmente, ésta, como ya se ha indicado, se extendió a otras materias. Entre ellas, hay que reseñar, en primer lugar, los cambios introducidos en relación con la Unión Europea, al constitucionalizar explícitamente el «espacio de libertad, seguridad y justicia», en el que Portugal está integrado como Estado miembro de la U.E.; pero, además, Portugal va a asumir como objetivo constitucional expreso su realización, a través de la cooperación (nueva noción introducida también en esta revisión), a añadir a los principios ya existentes de cohesión económica y social y de subsidiariedad ${ }^{122}$.

De esta forma, al tiempo que se proseguía y se completaba la tercera revisión de 1992 (originada y centrada, como sabemos, en el Tratado de la U.E. de Maastricht), se actualizaba la adaptación constitucional al proceso de integración europea tras el Tratado de Amsterdam (1997), que introduce la referencia al "espacio de libertad, seguridad y justicia» (ratificado después por el Tratado de Niza, en 2001). En conexión con esta nueva referencia constitucional a la cooperación en el es-

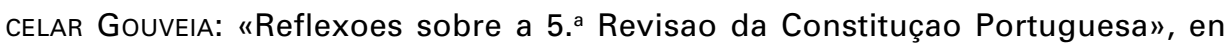
AA.VV.: Nos 25 anos da Constituiçao da República Portuguesa de 1976, AAFDL, 2001, pp. 629 y ss.

122 Sobre el principio de subsidiariedad en el marco eurocomunitario, vid. M. R. VILHENA: O principio da subsidiariedade no Direito comunitario, Lisboa, 2002; M. S. D'OlIVEIRA MARTINS: O principio da subsidiariedade em perspectiva jurídico-política, Coimbra, 2003. 
pacio de libertad, seguridad y justicia de la Unión Europea, se introducen también modificaciones en el régimen de extradición, puntualizando que el régimen general de la extradición contemplado en la Constitución portuguesa "no impide la aplicación de las normas de la cooperación judicial penal establecidas en el ámbito de la Unión Europea" (nueva redacción del n. ${ }^{\circ} 5$ del art. 33).

También dentro del ámbito de los derechos y libertades se introduce una modificación relativa a la inviolabilidad del domicilio durante la noche, garantía que se mantiene "salvo en situación de flagrante delito o mediante autorización judicial en casos de criminalidad especialmente violenta o altamente organizada, incluido el terrorismo y el tráfico de personas, armas o estupefacientes" (art. 34.3). Se trata, según apunta Barcelar Gouveia ${ }^{123}$, de una relajación de las garantías constitucionales sobre la inviolabilidad del domicilio que hay que situar en el contexto de los acontecimientos del 11 de Septiembre de 2001, en el que fue aprobada.

Otras modificaciones introducidas por esta revisión hacen referencia a la constitucionalización expresa del portugués como lengua oficial (art. 11); y, en conexión con el tema lingüístico, se constitucionaliza, así mismo, la equiparación de derechos para los ciudadanos de los Estados de lengua portuguesa con residencia permanente en Portugal en condiciones de reciprocidad (art. 15.3), en concordancia con lo dispuesto en la Constitución brasileña ${ }^{124}$; régimen aplicable solo a los referidos ciudadanos lusoparlantes, que disfrutarían así de algo parecido a un "régimen específico de ciudadanía» diferenciado al de cualquier otro ciudadano extranjero.

Finalmente, se aprovecha esta revisión constitucional para hacer algunas correcciones de carácter restrictivo en el régimen de derechos de los militares y los agentes militarizados, así como de los agentes de los servicios y de las fuerzas de seguridad del Estado, a quienes se podrá restringir, "en la estricta medida de las exigencias propias de sus respectivas funciones" (nueva redacción del art. 270) el ejercicio de algunos derechos tales como los de expresión, reunión, manifestación, asociación, petición colectiva y sufragio pasivo. En el caso de las fuerzas de seguridad, se puntualiza expresamente la no admisibilidad del

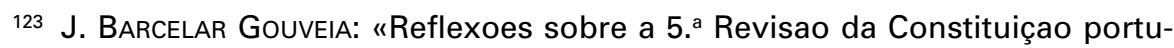
guesa", op. cit., p. 632.

${ }^{124}$ Art. 12.1 de la Constitución brasileña de 1988 y Tratado luso-brasileño de Porto Seguro, de 22 de abril de 2000 . Un breve comentario sobre la especificidad de las relaciones lingüísticas luso-brasileñas, en J. MIRANDA: Comenario al art. 15 (en particular, el n. ${ }^{\circ}$ 3), en Constituiçao Portuguesa Anotada, I, p. 134. 
derecho de huelga, sin perjuicio de que se admita para sus agentes el derecho de asociación sindical (art. 270).

\section{La revisión de 2005. La constitucionalización del (incierto) referéndum sobre la Constitución europea.}

La última, por ahora, y sin duda la más breve de todas las revisiones constitucionales - se limita a añadir un solo artículo (295) - tuvo lugar en el verano de $2005^{125}$. Como las anteriores de 1992 y 2001, tiene carácter extraordinario, lo que venía obligado por el hecho de que su tramitación se inicia cuando apenas han transcurrido unos meses desde que se aprueba la anterior (y sexta) revisión (Julio 2004); y también, al igual que aquellas (de 1992 y 2001), tiene su origen en un Tratado internacional; en este caso, el Proyecto de Tratado por el que se instituye una Constitución para Europa.

El proceso que conduce a la aprobación de esta séptima revisión constitucional se inicia inmediatamente después de la firma por Portugal (junto con los restantes miembros de la UE) del referido proyecto de Tratado Constitucional, con la Resolución de la Asamblea de la República ${ }^{126}$ anunciando que éste debería ser sometido a referéndum nacional. El problema que se planteaba era que, a la vista de las previsiones constitucionales en materia de referéndum (art.115), en particular los referéndums sobre Tratados internacionales, no estaba claro si era posible su realización directamente o, por el contrario, era preciso proceder a una revisión constitucional previa que autorizase el proyectado referéndum sobre el Tratado constitucional. La cuestión fue zanjada por el propio Tribunal Constitucional que, a requerimiento del Presidente de la República, se pronunció a favor de la previa revisión de la Constitución ${ }^{127}$.

El pronunciamiento explícito del T.C. sobre la cuestión, zanjando las eventuales controversias al respecto, despejaba cualquier obstáculo al desarrollo del proceso de revisión. Así, la Asamblea de la República asume, de inmediato, poderes extraordinarios de revisión ${ }^{128}$,

125 Lei Constitucional n. ${ }^{\circ}$ 1/2005 (Diário da República, I Serie A, n. ${ }^{\circ}$ 155, de 12 de Agosto de 2005).

${ }^{126}$ Resolución de la Asamblea de la República de 18 de Noviembre de 2004 (Diário da República, I A, n. ${ }^{\circ} 272$, de 19 de Noviembre de 2004.

127 Decisión del Tribunal Constitucional 704/2004 de 17 de Diciembre de 2004 (Diário da República, I A, n. ${ }^{\circ} 304$, de 30 de Diciembre de 2004).

128 Resolución de la Asamblea de la República 15/2005, de 7 de Abril (Diário da República, I A, n. ${ }^{\circ}$ 74, de 15 de Abril de 2005). 
seguida de la creación de la correspondiente Comisión para la Revisión constitucional extraordinaria, con participación en ella de todas las fuerzas políticas con representación parlamentaria. Finalmente, y tras un rápido debate en el seno de esta Comisión (tan sólo tres sesiones en una semana), se aprueba en el Pleno de la Asamblea por amplia mayoría, con los votos a favor del PS (101), PSD (63), CDS-PP (10), y en esta ocasión también del BE (7); y con la abstención del PCP (11) y de los verdes del PEV, que en todas las demás ocasiones habían votado en contra.

El legislador constitucional de 2005 se limita a puntualizar el significado y el alcance de una disposición constitucional ya existente -art. 115.3 , relativo a los supuestos que permiten la realización del referéndum - precisando que lo dispuesto en ella no impide "la posibilidad de convocatoria y realización de un referéndum sobre la aprobación de un Tratado que tenga como finalidad la construcción y la profundización de la Unión Europea». Se trata de una disposición de carácter interpretativo, un tanto extraña desde el punto de vista constitucional ya que no suelen ser frecuentes disposiciones de este tipo en los textos constitucionales, y que ha suscitado críticas en algunos medios doctrinales por entender que era innecesaria ${ }^{129}$.

Además de estas posiciones críticas, no tanto por oposición al referéndum sobre esta cuestión como por entender que la revisión no era necesaria para poder realizar éste, se ha aducido también la contradicción que supondría tener que emprender un proceso de revisión constitucional, que sería obligado a la vista de los importantes cambios introducidos por el proyecto de Tratado constitucional europeo, como consecuencia de un referéndum, lo que está expresamente excluido por la propia Constitución portuguesa (art. 115.4.a). En cualquier caso, es preciso constatar, como observa Rui Machete, que el proceso de integración europea, al margen de lo que decidan los respectivos órganos legislativos nacionales, comporta "un original proceso de revisión tácita de las respectivas Constituciones $"{ }^{130}$ de cada país miembro de la UE) como consecuencia inevitable de la propia dinámica de integración político-constitucional europea.

129 Entre las posiciones contrarias a la revisión constitucional, por considerarla innecesaria, vid. G. VAGLI: «Problematiche costituzionalistiche relative all'ammissibilitá in Portogallo del referéndum sul Trattato che instituisce una Costituzione per I'Europa", Diritto Pubblico Comparato ed Europeo, 2005-I, p. 94.

${ }_{130}$ RUI MACHETE: "O Referendo portugués sobre a Constituiçao Europeia. Uma nova forma de Revisao constitucional?", Revista de Relaçoes Internacionais, n. ${ }^{\circ} 5$, 2005, p. 22. 
Una vez efectuada la revisión constitucional para despejar todo obstáculo que impida realizar el referéndum sobre el proyecto de Tratado constitucional, el problema que se plantea ahora es su efectiva realización en la nueva situación creada tras el rechazo francés y holandés, también mediante referéndum, del proyecto de Tratado constitucional en ambos países, coincidiendo precisamente en el tiempo (Junio-Agosto 2005) con la aprobación de la última revisión constitucional portuguesa. En el momento actual (a punto de iniciarse la presidencia alemana de la UE durante el primer semestre de 2007), y a expensas de cómo se desarrollen los acontecimientos en la UE en relación con el Tratado constitucional, no parece previsible que en ninguno de los países de la UE se vayan a impulsar procesos de ratificación del proyecto de Tratado constitucional europeo mediante referéndum. Tampoco en Portugal parece previsible, a pesar de haber realizado con esta exclusiva finalidad su última, por ahora, revisión constitucional.

\section{Title}

Three decades of constitutional evolution in Portugal (1976-2006)

\section{Summary}

I. THE CONSTITUTIONAL SINGULARITY OF PORTUGAL. II. THE ORIGINAL VERSIONOF THE PORTUGUESE CONSTITUTION (1976). III. THE CONSTITUTIONAL REVISION. GENERAL CHARACTERISTICS AND DISTINCTIVE FEATURES OF THE PROCESS OF REVISION. IV. THE CONSTITUTIONAL RECTIFICATION. THE REVISIONS OF 1982 AND 1989. V. THE CONSTITUTIONAL REMODELING. THE REVISIONS OF 1997 AND 2004. VI. THE CONSTITUTIONAL ADAPTATION TO THE CHANGES IN THE INTERNATIONAL MARK. THE EXTRAORDINARY REVISIONS OF 1992, 2001 AND 2005.

\section{Resumen}

En este trabajo se analiza la evolución constitucional de Portugal, distinguiendo el distinto carácter de las sucesivas reformas, desde el momento de aprobación de la Constitución (1976), hasta las más recientes reformas con motivo, fundamentalmente, de la pertenencia de Portugal a la Unión Europea.

\section{Abstract}

In this study is analyzed the constitutional evolution of Portugal, distinguishing the different character of the successive reformations, from 
the moment of approval of the Constitution (1976), until the most recent reformations with reason, fundamentally, of the ownership of Portugal to the European Union.

\section{Palabras clave}

Constitución de Portugal, Evolución constitucional portuguesa.

\section{Key words} tion.

Constitution of Portugal (1976), Portuguese constitutional evolu- 